\title{
Use of portable environmental sensors in the monitoring of the thermoelectric power plants operation
}

Thermoelectric power plants can directly cause environmental impacts with respect to emissions of atmospheric gases caused by combustion for operation, being the main agents: unburne hydrocarbons, carbon oxides, sulfur oxides, nitrogen oxides, volatile organic compounds and material particulate. Thus, this research aimed to measure and compare the instantaneous levels of the chemical compounds $\mathrm{CO}$, $\mathrm{CO}$, SO2, noise, air temperature, relative humidity, dew point temperature, wind speed and luminescence in two peri-urban areas of the surrounding a thermoelectric power plant in the interior of Paraíba, Brazil. To this end, data were collected using environmental sensors (a Garmin Gpsmap 62sc GPS camera 5mp; a Canon powershot SX60HS 16.1MP LCD 3.0 semi-professional digital camera, 65x optical zoom; an ITMCO2-600 meter for measuring CO2 and CO; one ITMP-600 multifunctional meter for AVG/MAX/MIN/DIF measurement, temperature measurement, humidity measurement, sound level measurement, luminescence measurement and wind speed measurement; and a GasAlert Extreme SO2 Gas measurement, temperature measurement, humidity measurement, sound level measurement, luminescence measurement and wind speed measurement; and a GasAlert Extreme SO2 Gas
detector to measure concentrations of sulfur in the environment), from October 2015 to March 2017, during daytime, between 7:00am to 9:00am, with weekly frequency, with instantaneous detector to measure concentrations of sulfur in the environment), from October 2015 to March 2017, during daytime, between 7:00am to 9:00am, with weekly frequency, with instantaneous
sampling measurements being collected at the collection points, near the thermoelectric power plant (Area 1) and close to the BR/104 highway (Area 2). The results showed that the records through the environmental sensors were not significant among the areas surveyed regarding the values of $\mathrm{CO}, \mathrm{CO} 2$, $\mathrm{SO}$, air temperature, relative humidity, dew point temperature and luminescence. Regarding the wind speed, the two areas showed little variation. The noise levels in Area 1, on the other hand, during the operation of the thermoelectric power plant in it fullness, there was an increase above the permitted level, according to current Brazilian regulations, causing damage to the health of the inhabitants of its surroundings, in addition to harming the fauna of the surrounding area. around, mainly, the birds that are driven away by the noise, and, consequently, reducing the diversity of the avifauna surrounding the Thermoelectric. Thus, the use of environmental sensors to monitor the air quality of this area is very important, thus serving as a comparative support for future studies, as well as establishing the genesis for an environmental database in this metropolitan region of Campina Grande/PB, Brazil.

Keywords: Atmospheric pollutants; Air quality; Carbon dioxide; Atmospheric pressure; Decibels.

\section{Utilização de sensores ambientais portáteis no monitoramento do funcionamento das termelétricas} \begin{abstract}
As usinas termelétricas podem causar impactos ambientais diretos no que diz respeito às emissões de gases atmosféricos causados ??pela combustão para operação, sendo os principais agentes: hidrocarbonetos não queimados, óxidos de carbono, óxidos de enxofre, óxidos de nitrogênio, compostos orgânicos voláteis e material particulado. Assim, esta pesquisa teve como objetivo medir e comparar os niveis instantâneos dos compostos químicos $\mathrm{CO} 2$, $\mathrm{CO}, \mathrm{SO}$, ruido, temperatura do ar, umidade relativa, temperatura do ponto de orvalho, velocidade do vento câmera Garmin Gpsmap 62sc GPS 5mp; uma câmera digital semiprofissional Canon powershot SX60HS LCD 3.0 de 16.1MP, zoom óptico 65x; um medidor ITMCO2-600 para medir CO2 e CO; um ITMP -600 medidor multifuncional para medição de AVG/MAX/MIN/DIF, medição de temperatura, medição de umidade, medição de nível de som, medição de luminescência e medição de velocidade do vento; e um detector de gás GasAlert Extreme SO2 para medir as concentrações de enxofre no ambiente), a partir de outubro 2015 a março de 2017 , durante o dia, das 7 h00 às 9h00, com frequência semanal, sendo coletadas medidas de amostragem instantânea nos pontos de coleta, próximo à termelétrica (Área 1) e próximo à rodovia BR/104 (Área 2). Os resultados mostraram que os registros pelos sensores ambientais não foram significativos entre as áreas pesquisadas quanto aOs valores de $\mathrm{CO}, \mathrm{CO} 2, \mathrm{SO} 2$, temperatura do ar, umidade relativa, temperatura pon os re or durante aperço da permettica de prejudicar a fauna do entorno. ao redor, principalmente, das aves que são afugentadas pelo barulho e, consequentemente, reduzindo a diversidade da avifauna no entorno da Termelétrica. Assim, a utilização de sensores ambientais para monitorar a qualidade do ar desta área é muito importante, servindo assim como um suporte comparativo para estudos futuros, bem como estabelecer a gênese para um banco de dados ambiental nesta região metropolitana de Campina Grande/PB, Brasil.
\end{abstract}

Palavras-chave: Poluentes atmosféricos; Qualidade do ar; Dióxido de carbono; Pressão atmosférica; Decibéis.

Topic: Conservação da Biodiversidade

Reviewed anonymously in the process of blind peer.

Joaci dos Santos Cerqueira (iD)

Universidade Federal de Campina Grande, Brasil

http://lattes.cnpq.br/4470582307237189

http://orcid.org/0000-0002-0109-3849

cerq2006@gmail.com

Helder Neves de Albuquerque

Universidade Federal de Campina Grande, Brasil

http://lattes.cnpq.br/1316763030688970

http://orcid.org/0000-0002-5076-3060

helderbiologo@gmail.com

Mário Luiz Farias Cavalcanti (iD)

Universidade Federal da Paraíba, Brasil

http://lattes.cnpq.br/1805345433854856

http://orcid.org/0000-0002-9505-417X

mariolfcavalcanti@yahoo.com.br

DOI: 10.6008/CBPC2179-6858.2020.006.0016
Received: 04/10/2020

Approved: 21/11/2020

Francisco de Assis Salviano de Sousa (iD

Universidade Federal de Campina Grande, Brasil

http://lattes.cnpq.br/5392432872592612

http://orcid.org/0000-0002-4085-0785

fsouza2011@gmail.com
Referencing this:

CERQUEIRA, J. S.; ALBUQUERQUE, H. N.; CAVALCANTI, M. L. F.; SOUSA, F. A. S.. Use of portable environmental sensors in the monitoring of the thermoelectric power plants operation. Revista Ibero Americana de Ciências Ambientais, v.11, n.6, p.178-201, 2020. DOI: 


\section{INTRODUCTION}

The lack of long-term planning in Brazil's energy policy and the current water crisis has directly reflected in the generation of electric energy by hydroelectric plants, thus requiring the activation of a greater number of thermoelectric power plants in the country to guarantee energy demand (GALVÃO et al., 2015).

Currently, the Brazilian energy matrix is made up of 7,420 generating companies, 217 of which are Hydroelectric Plants (HP), 426 Small Hydroelectric Plants (SHP), 698 Hydropower Plants (HPP), 1 WavesElectric Power Station (WEPS), 3001 Thermoelectric Power Plants (TPP), 2 Thermonuclear Plants (TP), 606 Wind Generating Plants (WGP) and 2,469 Solar Photovoltaic Generating Plants (SPGE). Of the total thermoelectric power plants, 2,251 are powered by fuel oil and diesel (ANEEL, 2019).

The generation of energy by thermoelectric power plants, in addition to being more expensive, provides greater atmospheric contamination and generates liquid effluents on a large scale. Attention is drawn to the fact that when generating $1 \mathrm{MWh}$ of electricity in a Thermoelectric power Plant (TPP) that uses heavy oil HFO (Heavy Fuel Oil), whose composition contains hydrocarbons with 50 carbon atoms and 2.5\% sulfur, 4,373kg of Particulate Material (PM), 29,401 kg of Carbon Dioxide $\left(\mathrm{CO}_{2}\right), 1,133 \mathrm{~kg}$ of Carbon Monoxide (CO), $10,631 \mathrm{~kg}$ of Sulfur Dioxide $\left(\mathrm{SO}_{2}\right), 45,178 \mathrm{~kg}$ of Nitrous Oxide (NO) and $29,401 \mathrm{~kg}$ of Dioxide Nitrogen $\left(\mathrm{NO}_{2}\right)$ (COLOSSI, 2012).

In this context, for control and monitoring of the quality of atmospheric air, the National Environment Council established, through CONAMA Resolution no 003/1990, standards for concentrations of atmospheric pollutants (CONAMA, 1990). When these standards are exceeded, they can affect the health, safety and wellbeing of the population, in addition to causing damage to flora and fauna, materials and the environment in general. However, respirable particles are not included in this resolution, which are responsible for causing respiratory and skin diseases in a short time of exposure (KAMPA et al., 2008). Therefore, as they are frequently linked to the occurrence and adverse effects that harm the environment, $\mathrm{SO}_{2}, \mathrm{O}_{3}, \mathrm{CO}, \mathrm{NO}_{2}$ gases, Total Suspended Particles (TSP) and Total Hydrocarbons (TH) are considered as indicators of air quality (SOUSA, 2016).

Among the harmful pollutants emanating from the thermoelectric power plants in operation, it is noteworthy that $\mathrm{SO}_{2}$ is a pollutant of mainly industrial origin, which is generated through combustion processes (heavy oil, coal, gasoline, among others). In humans, it can cause irritation of the membranes, mucous membranes and respiratory tract with the appearance of pulmonary edema and bronchitis (DRUMM et al., 2014; SINGH et al., 2008).

In vegetables, the severity of the damage caused by $\mathrm{SO}_{2}$ depends on the maturity of the leaves, the young ones being more sensitive to $\mathrm{SO}_{2}$ than the older leaves. In dicots, the damage caused by $\mathrm{SO}_{2}$ usually manifests as leaf necrosis. In monocotyledons, in low and moderate concentrations, $\mathrm{SO}_{2}$ can cause damage to the top of the leaves. Therefore, the sensitivity between plant species depends on the sensitivity and the degree of exposure to $\mathrm{SO}_{2}$ (MARIANO, 2001). As for tropospheric ozone, the plants when exposed suffer serious damage, consequently, brings significant agricultural losses. In some metropolitan regions of Brazil, 
the average annual concentrations reach $45 \mathrm{ppb}$ (part per billion), which is already considered sufficient to cause severe toxic effects on plants (PEDROSO, 2007).

In humans, acute carbon monoxide poisoning leads to unintended and unrelated mortality and morbidity, thus causing a substantial public health problem, but they are often unknown (GRABER et al., 2007). In Thermoelectric power Plants, the release of carbon monoxide generally occurs when the burning of fuel in the energy boilers is incomplete, due to errors in combustion (ATĂNĂSOAE, 2009). Carbon dioxide gas, on the other hand, is characterized by being non-toxic and non-flammable, as it has no odor and color, leaks are impossible to detect. Exposure to high concentrations of $\mathrm{CO}_{2}$ can generate risks to human health, when inhaled in large quantities, it can cause irritation in the airways, vomiting, nausea and even death from asphyxiation, a fact that often occurs in fires. The typical concentration in the atmosphere is 350 to $450 \mathrm{ppm}$ (SERAFIM, 2008; VAISALA, 2012).

In this sense, it is observed that in the atmosphere the concentration of polluting gases has been increasing considerably, since the 18th century, thus potentiating acid rain, the elevation of local temperature, the degradation of ecosystems and landscapes, with losses to food production (LE QUÉRÉ et al., 2009; SILVA et al., 2007; SOUZA et al., 2008).

Thus, in this study, measuring the levels of atmospheric gases using environmental sensors in the surroundings of Borborema S.A. thermal power plant is of paramount importance, in order to allow the generation of a database of the collected values and to allow comparisons of these levels, during the period of operation and non-operation of the thermoelectric plant. It should also be noted that the operation of the thermoelectric plant is conditioned to the energy policy of the current Brazilian government situation.

To this end, this research aimed to measure and compare the instantaneous levels of chemical compounds $\mathrm{CO}_{2}, \mathrm{CO}, \mathrm{SO}_{2}$, noise, air temperature, relative humidity, dew point temperature, wind speed and luminescence in two peri-urban areas of the surrounding a thermoelectric power plant in the interior of Paraíba, Brazil.

\section{MATERIALS AND METHODS}

This study was the result of a doctoral thesis in Natural Resources at the Federal University of Campina Grande (UFCG), Paraíba, Brazil, during the period of 2014-2018.

\section{Characterization of the study area}

The research was carried out in two study areas, area 1 (Figure 1) comprised the surroundings of the (TPP) Borborema S.A. thermal power plant., which is located in the municipality of Queimadas-PB; to the north, Campina Grande airport is located, at 2,900 meters; to the south, is the city of Queimadas-PB; to the West, it locates a typical caatinga vegetation, comprising the transition zone from urban to rural of Campina Grande and to the East, it is limited by BR 104/south, at 1,735 meters from it. 


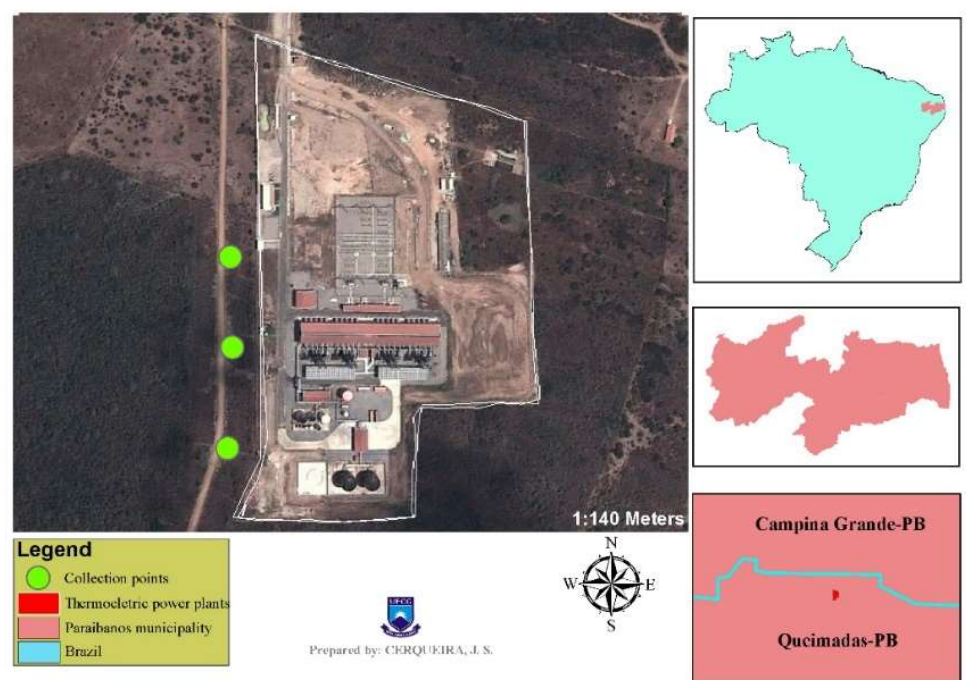

Figure 1: Identification of Area 1 around the Borborema S.A. thermal power plant Queimadas-PB, Brazil, 2017.

Area 2 (Figure 2) is located in the Aluízio Campos Complex (ACC), which was named as an experimental area, located at a distance of 2.200 meters from the Borborema S.A. thermal power plant. In this area, the same methodological procedures as in area 1 were also used, the choice being made intentionally, as it is located in the Northeast part of the TPP, which is contrary to the prevailing winds of the municipality of Campina Grande-PB. Thus, it is emphasized that the wind direction is of fundamental relevance to the procedures performed in the collection of atmospheric data.

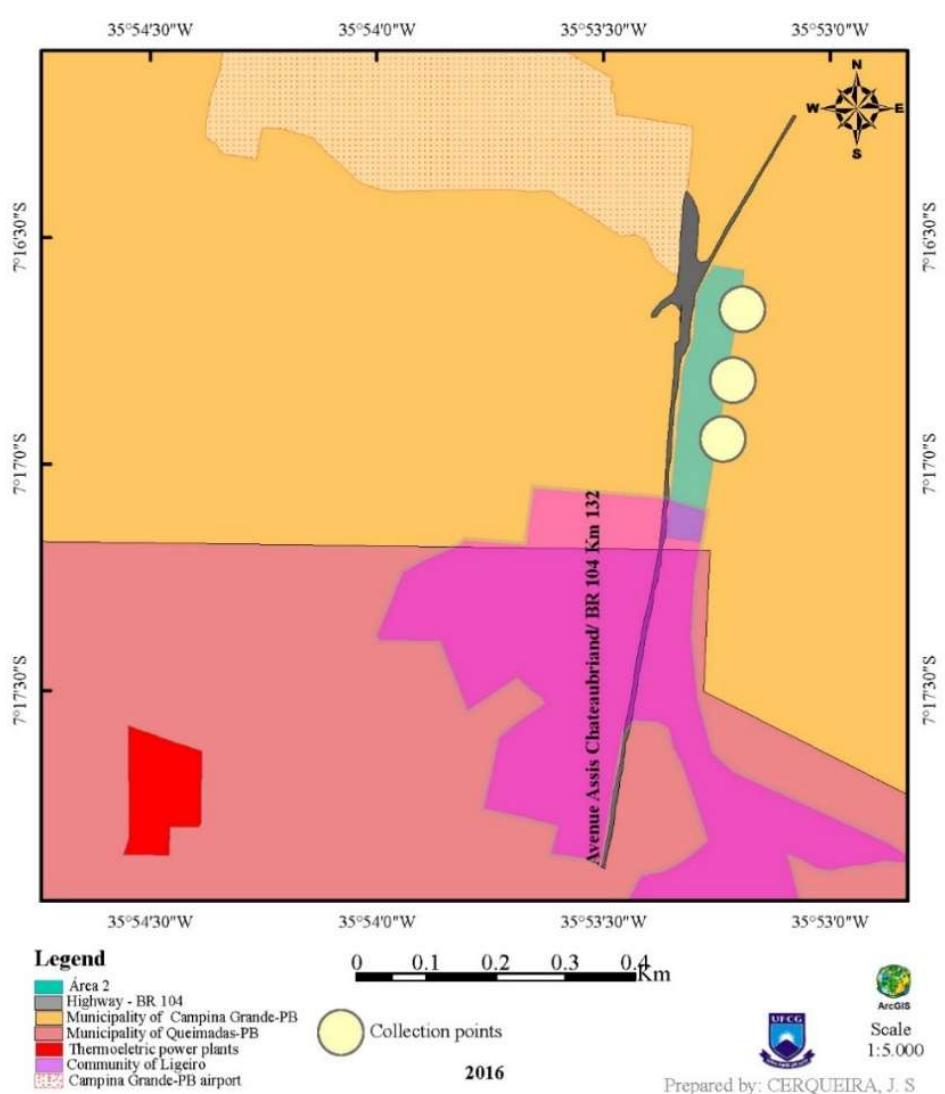

Figure 2: Structural map with identification of Area 2. Campina Grande-PB, Brazil, 2017.

The Borborema S.A. thermal power plant produces electrical energy by combustion, being used in this process, the heavy oil (HFO) that needs to be kept warm constant at the operating temperature for 
immediate use. The TPP has 20 chimneys, in 4 towers with 5 ducts each, and its energy production capacity reaches $169 \mathrm{MW}$, which guarantees energy to supply a population of more than five hundred thousand inhabitants (CAL, 2008).

The TPP facilities occupy a physical area of 12,50 hectares located at the geographical coordinates $7^{\circ} 17^{\prime} 47.44^{\prime \prime S} 35^{\circ} 54^{\prime} 30.29 " O$, whose altitude is 483 meters (GOOGLE EARTH, 2017). Thus, the UTE is located close to the neighborhood of Ligeiro, in the municipality of Queimadas-PB, however, for administrative purposes, the thermoelectric plant is considered a constant undertaking in the municipality of Campina Grande-PB.

The neighborhood of Ligeiro is politically administered by the municipality of Queimadas, which has a population of around 3,692 inhabitants, being the most populated area in the municipality. However, the Ligeiro is not an area contiguous to the headquarters of the municipality of Queimadas. Therefore, its location as a residential area is in a borderline area between the North of Queimadas-PB and the South of Campina Grande-PB (IBGE, 2010; SILVA et al., 2010).

\section{Methodological procedures}

Data collection using environmental sensors took place from October 2015 to March 2017, during daytime hours, between 7:00am to 9:00am, with weekly frequency, with instantaneous sampling measurements being collected at the collection points, close to TPP (area 1) and close to highway BR/104 (area 2). Regarding the conditions for collecting the information, it was in temperature and natural environment. Collections were performed with instruments (environmental sensors) at a height of two meters from ground level.

\section{Data collection instruments}

As a data collection instrument, the following equipment/environmental sensors were used: a Garmin GPS Gpsmap 62sc camera 5mp; a Canon powershot SX60HS 16.1MP LCD 3.0 semi-professional digital camera, 65 x optical zoom; an ITMCO -600 meter for measuring $\mathrm{CO}_{2}$ and $\mathrm{CO}$; an ITMP-600 multifunctional meter for AVG/MAX/MIN/DIF measurement, temperature measurement, humidity measurement, sound level measurement (dB), luminescence measurement (Lux) and wind speed measurement; a GasAlert Extreme $\mathrm{SO}_{2}$ Gas detector to measure sulfur concentrations in the environment.

The ITMCO $2-600$ Multifunctional Meter has a USB port for PC interface measures up to 6 variables in a single device $\left(\mathrm{CO}_{2}, \mathrm{CO}\right.$, temperature, relative humidity and dew point). The ITMCO $2-600$ is an ideal instrument for diagnosing indoor air quality (IAQ), especially $\mathrm{CO}_{2}$ levels and air ventilation. Therefore, it is widely used in public areas such as offices, classrooms, factories, hospitals and hotels. Its use is also suggested in the regulation of industrial hygiene in some countries, in addition to being used to check the performance of the HVAC heating, ventilation and air conditioning system and the level of $\mathrm{CO}_{2}$ and $\mathrm{CO}$ in open areas (INSTRUTEMP, 2016c).

Instrutemp's ITMP-600 multifunctional meter is capable of measuring temperature, humidity, sound 
intensity, light intensity and wind speed. It should also be noted that it is an instrument widely used in occupational safety that has several functions, thus making it possible to diagnose environmental variables at a given time, quickly and accurately (INSTRUTEMP, 2016b).

The GasAlert Extreme $\mathrm{SO}_{2}$ gas detector is a device that makes it possible to measure sulfur concentrations in the environment. It is emphasized that the GasAlert detector is the instrument very sensitive to changes in air quality, which and is often used to monitor air quality in the air interior and exterior of buildings (buildings, houses, schools, among others) (INSTRUTEMP, 2016a; NAGENDRA et al., 2010).

Regarding the calibration of the instruments, they are carried out every two years, or when the instrument needs calibration at any time by the measuring instruments company, INSTRUTEMP, based in São Paulo-SP. Meteorological data from the Automatic Meteorological Station of Campina Grande-PB (A-313), made available online by the National Meteorological Institute (INMET, 2010), were used.

\section{Software used}

For the transfer of $\mathrm{CO}_{2}$ and $\mathrm{CO}$ data recorded in $\mathrm{ITMCO}_{2}-600$, the Log Express software (INSTRUTEMP, 2016d) was used. As for making the wind rose, the software WRPLOT View TM 8.0.0-Freeware from Lakes Environmental was used. All environmental data were treated statistically by the XLStat (Freeware) and StatAction (Pro version) software with an interface in Excel software, 2016. And for the georeferencing of the areas surveyed, the GPS TrackMaker ${ }^{\circledR}$ Free version 13.9.591, ArcMap 10.1 (licensed to the Laboratory of Digital Cartography, Geoprocessing and Remote Sensing of Postgraduate courses at the Humanities Center of the Federal University of Campina Grande) and Google Earth (C) (2017).

\section{RESULTS AND DISCUSSION}

It is noteworthy that the Borborema S.A. thermal power plant during the period of this research functioned few times, on the occasion of the 'Red Flag' authorization carried out by the National Electric Energy Agency (ANEEL), or on the occasion of preventive maintenance of the thermoelectric. It is thus emphasized that the system of tariff flags has existed since 2015, and aims to signal to consumers about the real cost of energy generation, where thermoelectric plants are activated to guarantee the national energy supply and, consequently, the cost this generation is passed on to the consumer (ANEEL, 2015).

Regarding the $\mathrm{SO}_{2}$ measurements performed through the GasAlert Extreme $\mathrm{SO}_{2}$ Gas Sensor/Detector, the data were zero, with no record of occurrence of sulfur dioxide in either of the two areas surveyed. Thus, it is evident that even when the Borborema S.A. thermal power plant was in operation, there was no record in part per million (ppm), for $\mathrm{SO}_{2}$ at the collection points. It is also observed that the collections in area 1 were carried out at 100 meters from the pollutant emitting source, and that this source is 35 meters high.

As for the levels of carbon monoxide (CO) it was also found that the values were zero in the two areas surveyed, characterizing in this way that the burning of HFO oil at the Borborema S.A. thermal power plant is being efficient during the process of generating electricity. That is, taking into account the measurement 
at 100 meters from the emitting source, this distance has already been mentioned previously.

For Guimarães (2011), carbon monoxide is an intermediate product resulting from the combustion process, where low oxygen concentration occurs. To better understand this situation, Chevron (2004) highlights that combustion with diesel oil is a petroleum derivative used in automotive internal combustion engines by compression, which achieves the highest yields $(45 \%)$, compared to other fuels of internal combustion. The cycle of this oil in the engine is regulated only by the fuel flow, since the air flow remains constant with changes in speed, as these engines generally operate with excess oxygen, hydrocarbon and carbon monoxide emissions are minimized (CHEVRON, 2004; MASSAGARDI, 2004).

Therefore, the burning of fossil fuels (gasoline and diesel) happens incompletely when used in thermal machines and motor vehicles, this process results in the release of a large amount of carbon monoxide and dioxide into the atmosphere (DRUMM et al., 2014).

As for $\mathrm{SO}_{2}$ emissions, according to FEEMA (2004) $88 \%$ of sulfur dioxide emissions are from fixed sources and $12 \%$ are from vehicle sources. For Silva et al. (2013b), the high emissions of $\mathrm{SO}_{2}$ in the atmosphere cause serious damage to human health, and in contact with atmospheric humidity it generates sulfuric acid $\left(\mathrm{H}_{2} \mathrm{SO}_{4}\right)$, which contributes considerably to the formation of acid rain and can acidify soil and water, also harming the development of algae and insects.

On Table 1, it was observed that the $\mathrm{CO}_{2}$ levels did not present an expressive / significant value measured, both in area 1 and in area 2, even when the UTE was operating. The highest instantaneous values were $\left(\mathrm{CO}_{2}=372\right)$, dated $04 / 20 / 2016$, where five TPP chimneys were in operation, and $\left(\mathrm{CO}_{2}=368\right)$ dated 05/11/2016, with the TPP disconnected. In this way, it was also observed that the $\mathrm{CO}_{2}$ record was directly higher in the same date in area 2. This approach addresses the strong positive correlation between the variables, being $(R=0,845)$ and the determination coefficient $\left(R^{2}=0,715\right)$, thus showing that $71 \%$ of the $\mathrm{CO}_{2}$ variations in area 2 are explained by the variations in area 1 . Thus characterizing direct proportionality.

For Amaral et al. (2009), the Linear correlation between two variables when the value is close to 1 shows a strong linear relationship between the variables, and to assess whether this result is significant, a Hypothesis Test for the Correlation Coefficient can be performed.

As for the instantaneous measurements of Ambient Temperature, Relative Air Humidity, Dew Point Temperature and Wet Bulb Temperature of the surveyed areas, the recorded data did not present any value outside the normal range to those recorded by meteorological stations installed in the city of Campina Grande- PB. Where in the studied period the ambient temperature varied from $22^{\circ} \mathrm{C}$ to $30^{\circ} \mathrm{C}$, the $\mathrm{RH}$ was between $89,8 \%>54,7 \%$, the DPT was between $22,2^{\circ} \mathrm{C}>14,1^{\circ} \mathrm{C}$ and the registered WBT varied from $23,9>18,1^{\circ} \mathrm{C}$

In this way, the temporal distribution of the instantaneous measurements of Ambient Temperature in Areas 1 and 2 showed correlation $(R=0,711)$, thus characterizing it as a moderate and determined correlation $\left(R^{2}=0,505\right)$, and representing about $50 \%$ of interference from $A 2$ with respect to $A 1$.

Regarding the decibel levels, there was significance for the values when the TPP was in operation, with a variation of $48 \mathrm{~dB}$ (five connected chimneys) to $66,7 \mathrm{~dB}$ (twenty connected chimneys). The noise levels 
in area 2 had little variation $(39,9>53,8 \mathrm{db})$. It can also be seen that when the TPP was off, the noise levels were $43,5>49,6 \mathrm{~dB}$, since even the TPP was off, the transfer pumps for feeding the "lung" tanks were functioning. Where the HFO is heated to approximately $60^{\circ} \mathrm{C}$, which is the nominal temperature of these tanks that function as intermediate storage before the HFO fuel separator. This way, the fuel oil is ready for immediate use.

As for the temporal distribution of instantaneous Decibel measurements, in areas 1 and 2 there was a weak positive correlation $(R=0,106)$, where there was little interference $(1,13 \%)$ of area 2 in area 1 , with the determination coefficient $\left(R^{2}=0,0113\right)$.

It is also approached that the luminescence recorded in the study period was consistent with the climatic conditions of Campina Grande-PB, registered for this sector of the Northeast region, with predominance of partly cloudy days, and with sky between clouds.

As for the correlation and determination of the temporal distribution of instantaneous luminescence measurements in Areas 1 and 2, it was $R=0,638$ and determination $R^{2}=0,407$, thus representing a moderate correlation between the variables $(40,7 \%)$.

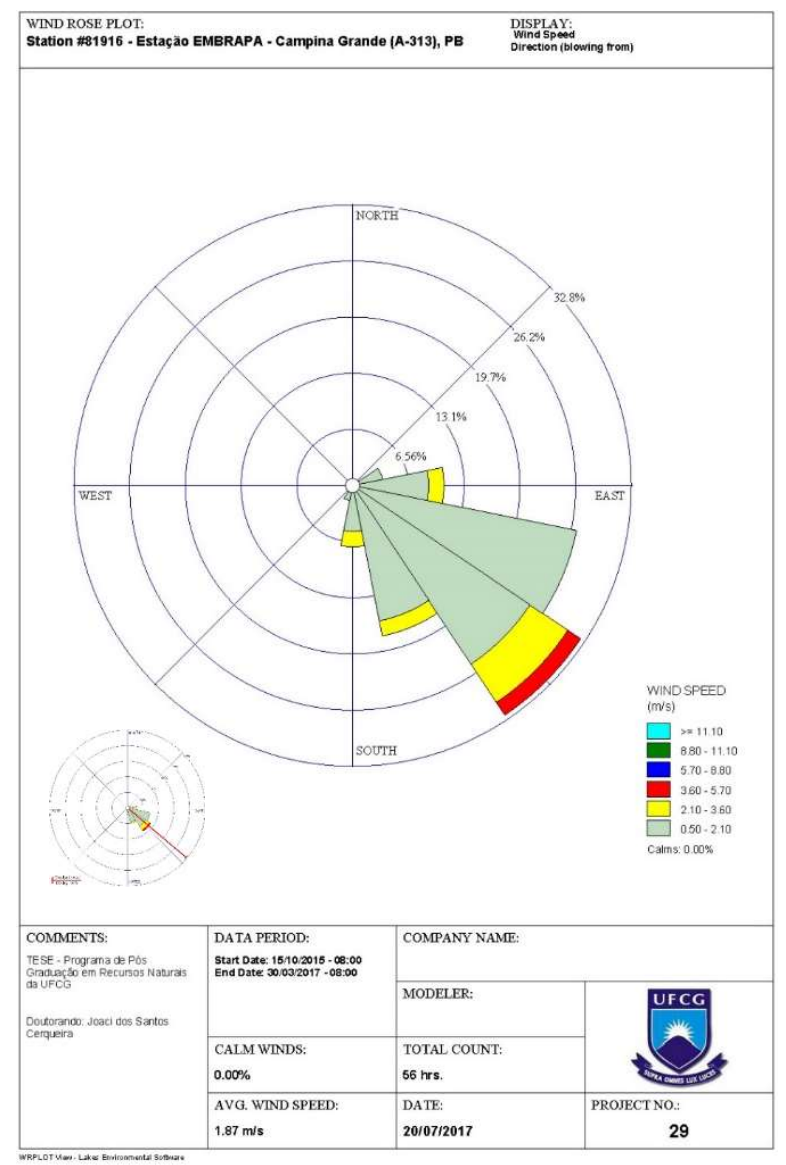

Figure 3: Wind speed and direction study Area 1. Queimadas-PB, Brazil, 2017.

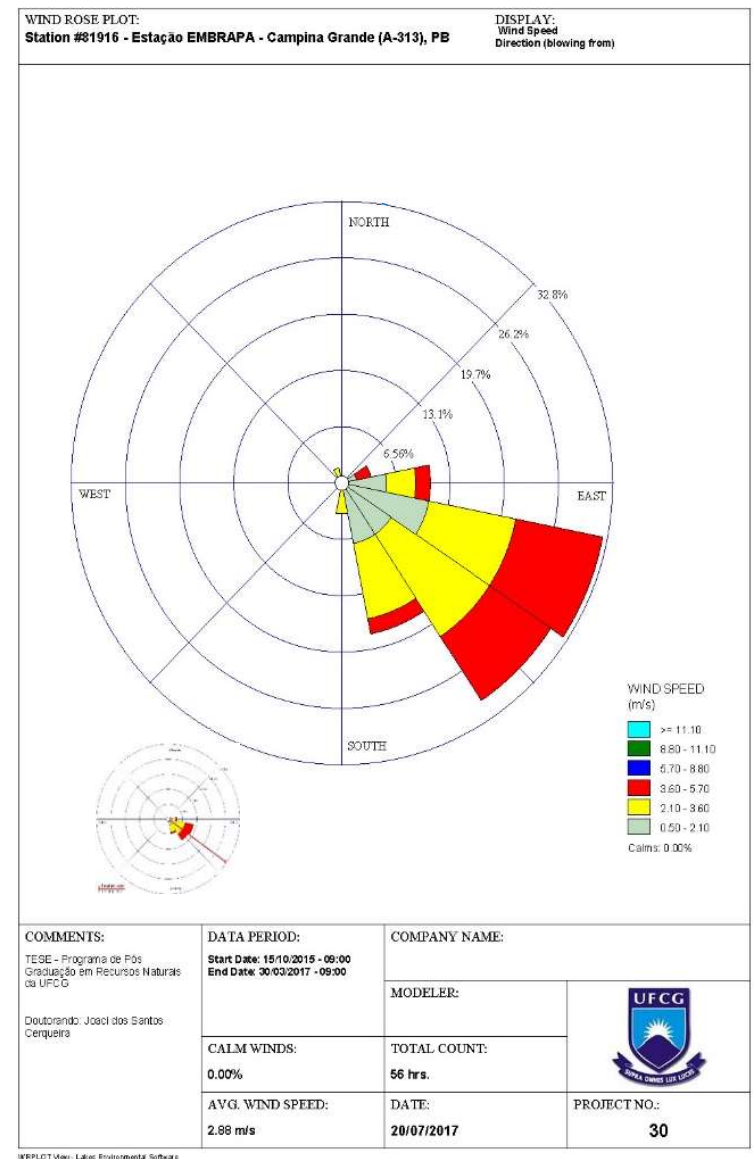

Figure 4: Wind speed and direction study Area 2. Campina Grande-PB, Brazil, 2017.

To better visualize the data related to wind speed and direction, the software WRPLOT View TM 8.0.0-Freeware from Lakes Environmental was used, where a wind rose was made. In area 1, the average wind speed recorded (UTC=8h) was $1,87 \mathrm{~m} / \mathrm{s}$ (Figure 3), and in area 2 (UTC=9h), 2,88m/s (Figure 4), with both 
areas the predominant wind direction was $88 \%$ in the Southeast (SO) direction, for the period considered in the study. Regarding gusts, there was no significance in both areas (Gust $A 1=1,8<6,5 \mathrm{~m} / \mathrm{s}$ ) and (Gust $A 2=1,9<7,6 \mathrm{~m} / \mathrm{s})$.

It was also found, according to Table 1, that the relative atmospheric pressure (RAP) did not vary significantly during the period of records with environmental sensors in this study, with the maximum and minimum variations for $\mathrm{RAP}=957<969,7$.

The correlation and determination parameters showed a strong positive correlation $(R=0,995)$, with determination $\left(R^{2}=0,99\right)$, thus representing $99,02 \%$ of $A 2$ interference in relation to $A 1$. This fact is justifiable, since the Atmospheric Pressure values of $A 2$ are the same as those of $A 1$.

Table 1: Environmental data, referring to the TPP surroundings, from October 2015 to March 2017. Queimadas-PB, Brazil. 2017

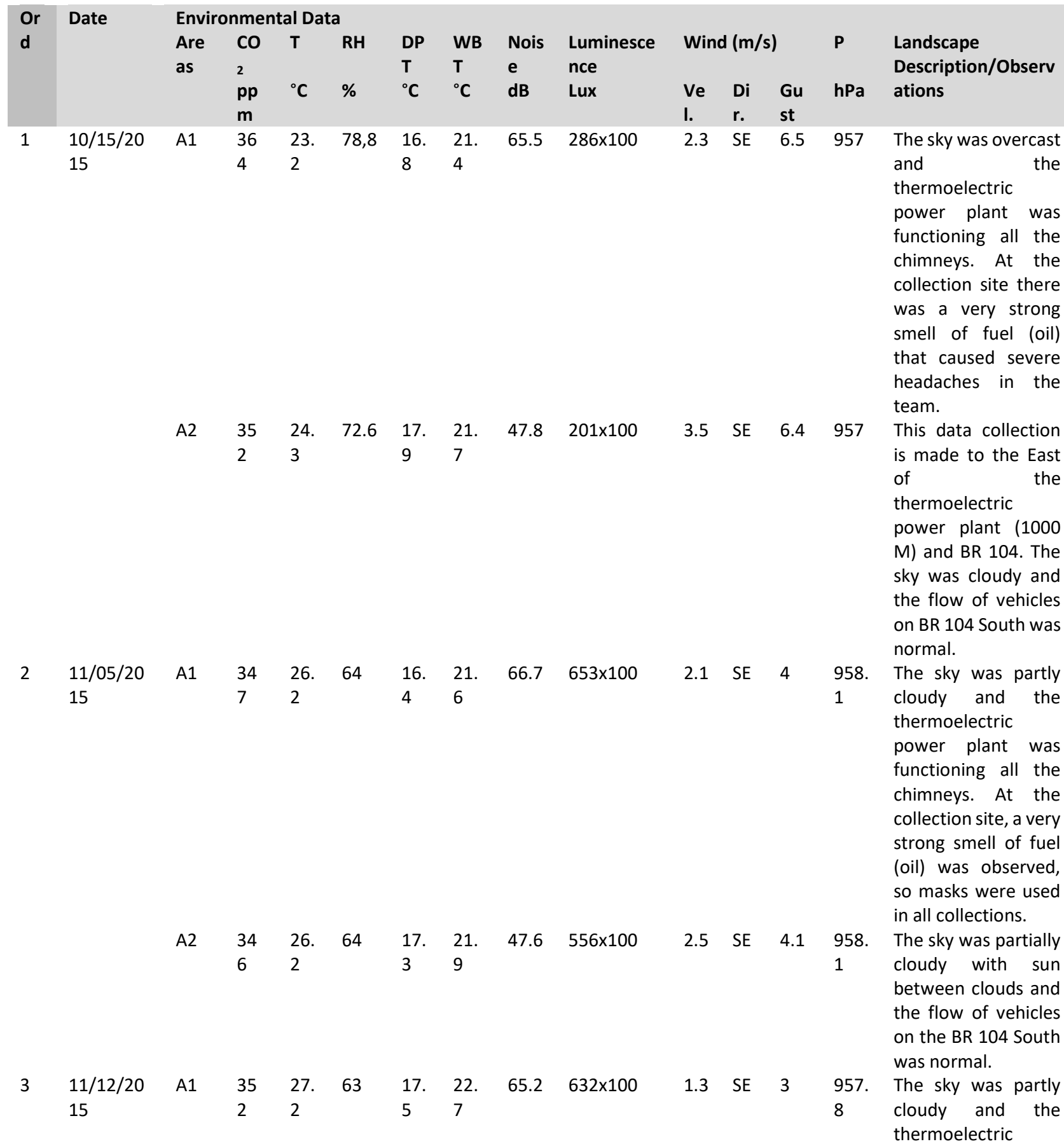




\begin{tabular}{|c|c|c|c|c|c|c|c|c|c|c|c|c|c|c|}
\hline & & $\mathrm{A} 2$ & 34 & 27. & 64 & 17. & 22. & 46.1 & $558 \times 100$ & 3.1 & SE & 5.2 & 957. & $\begin{array}{l}\text { chimneys. } \\
\text { The sky was partially }\end{array}$ \\
\hline & & & 9 & 3 & & 2 & 2 & & & & & & 8 & $\begin{array}{l}\text { cloudy with sun } \\
\text { between clouds and } \\
\text { the flow of vehicles } \\
\text { on the BR } 104 \text { South } \\
\text { was normal. }\end{array}$ \\
\hline 4 & $\begin{array}{l}11 / 19 / 20 \\
15\end{array}$ & $\mathrm{~A} 1$ & $\begin{array}{l}34 \\
9\end{array}$ & $\begin{array}{l}26 . \\
8\end{array}$ & 64 & $\begin{array}{l}16 . \\
9\end{array}$ & $\begin{array}{l}21 . \\
8\end{array}$ & 65.1 & $544 \times 100$ & 1.9 & L & 4.2 & 958 & $\begin{array}{l}\text { The sky was partly } \\
\text { cloudy and the } \\
\text { thermoelectric } \\
\text { power plant was } \\
\text { functioning all the } \\
\text { chimneys. }\end{array}$ \\
\hline & & $\mathrm{A} 2$ & $\begin{array}{l}34 \\
7\end{array}$ & $\begin{array}{l}27 . \\
4\end{array}$ & 63 & $\begin{array}{l}16 . \\
9\end{array}$ & $\begin{array}{l}21 . \\
7\end{array}$ & 47.2 & $577 \times 100$ & 3.4 & L & 5.3 & 958 & $\begin{array}{l}\text { The sky was partially } \\
\text { cloudy with sun } \\
\text { between clouds and } \\
\text { the flow of vehicles } \\
\text { on the BR } 104 \text { South } \\
\text { was normal. }\end{array}$ \\
\hline 5 & $\begin{array}{l}11 / 26 / 20 \\
15\end{array}$ & $\mathrm{~A} 1$ & $\begin{array}{l}35 \\
5\end{array}$ & $\begin{array}{l}27 . \\
1\end{array}$ & 66 & $\begin{array}{l}17 . \\
3\end{array}$ & $\begin{array}{l}22 . \\
4\end{array}$ & 64.9 & $466 \times 100$ & 2.1 & L & 4.7 & 960 & $\begin{array}{l}\text { The sky was partly } \\
\text { cloudy and the } \\
\text { thermoelectric } \\
\text { power plant was } \\
\text { functioning all the } \\
\text { chimneys. }\end{array}$ \\
\hline & & $\mathrm{A} 2$ & $\begin{array}{l}35 \\
1\end{array}$ & $\begin{array}{l}27 . \\
5\end{array}$ & 66 & $\begin{array}{l}17 . \\
4\end{array}$ & $\begin{array}{l}22 . \\
6\end{array}$ & 48.1 & $455 \times 100$ & 3.8 & L & 5.4 & 960 & $\begin{array}{l}\text { The sky was partially } \\
\text { cloudy with sun } \\
\text { between clouds and } \\
\text { the flow of vehicles } \\
\text { on the BR } 104 \text { South } \\
\text { was normal. }\end{array}$ \\
\hline 6 & $\begin{array}{l}12 / 08 / 20 \\
15\end{array}$ & $\mathrm{~A} 1$ & $\begin{array}{l}34 \\
1\end{array}$ & $\begin{array}{l}28 . \\
6\end{array}$ & $\begin{array}{l}56.8 \\
0\end{array}$ & 19 & $\begin{array}{l}21 . \\
5\end{array}$ & 49.4 & $560 \times 100$ & 2.4 & L & 5.5 & 957 & $\begin{array}{l}\text { The sky was partly } \\
\text { cloudy and the } \\
\text { power plant was } \\
\text { turned off. }\end{array}$ \\
\hline & & $\mathrm{A} 2$ & $\begin{array}{l}34 \\
0\end{array}$ & $\begin{array}{l}28 . \\
7\end{array}$ & $\begin{array}{l}57.9 \\
0\end{array}$ & $\begin{array}{l}19 . \\
1\end{array}$ & $\begin{array}{l}21 . \\
7\end{array}$ & 47.5 & $566 \times 100$ & 4.1 & $\mathrm{~L}$ & 5.6 & 957 & $\begin{array}{l}\text { The sky was partially } \\
\text { cloudy with sun } \\
\text { between clouds and } \\
\text { the flow of vehicles } \\
\text { on the BR } 104 \text { South } \\
\text { was normal. }\end{array}$ \\
\hline 7 & $\begin{array}{l}12 / 19 / 20 \\
15\end{array}$ & $\mathrm{~A} 1$ & $\begin{array}{l}33 \\
9\end{array}$ & $\begin{array}{l}29 . \\
3\end{array}$ & $\begin{array}{l}55.6 \\
0\end{array}$ & $\begin{array}{l}17 . \\
7\end{array}$ & $\begin{array}{l}20 . \\
1\end{array}$ & 41.2 & $545 \times 100$ & 2.6 & L & 5.9 & 960 & $\begin{array}{l}\text { The sky was partly } \\
\text { cloudy and the } \\
\text { thermoelectric } \\
\text { power plant had five } \\
\text { chimneys. }\end{array}$ \\
\hline & & $\mathrm{A} 2$ & $\begin{array}{l}34 \\
2\end{array}$ & $\begin{array}{l}29 . \\
4\end{array}$ & $\begin{array}{l}56.7 \\
0\end{array}$ & $\begin{array}{l}17 . \\
9\end{array}$ & $\begin{array}{l}20 . \\
6\end{array}$ & 48.4 & $588 \times 100$ & 3.9 & L & 6.3 & 960 & $\begin{array}{l}\text { The sky was partially } \\
\text { cloudy with sun } \\
\text { between clouds and } \\
\text { the flow of vehicles } \\
\text { on the BR } 104 \text { South } \\
\text { was normal. }\end{array}$ \\
\hline 8 & $\begin{array}{l}12 / 28 / 20 \\
15\end{array}$ & $\mathrm{~A} 1$ & $\begin{array}{l}33 \\
6\end{array}$ & $\begin{array}{l}28 . \\
4\end{array}$ & $\begin{array}{l}66.4 \\
0\end{array}$ & $\begin{array}{l}16 . \\
8\end{array}$ & $\begin{array}{l}20 . \\
9\end{array}$ & 51.5 & $545 \times 100$ & 2.4 & SE & 5.2 & 960 & $\begin{array}{l}\text { The sky was partly } \\
\text { cloudy and the } \\
\text { thermoelectric } \\
\text { power plant had five } \\
\text { chimneys. }\end{array}$ \\
\hline & & $\mathrm{A} 2$ & $\begin{array}{l}34 \\
7\end{array}$ & $\begin{array}{l}28 . \\
5\end{array}$ & $\begin{array}{l}67.2 \\
0\end{array}$ & $\begin{array}{l}17 . \\
2\end{array}$ & $\begin{array}{l}21 . \\
5\end{array}$ & 47.9 & $603 \times 100$ & 3.1 & SE & 5.4 & 960 & $\begin{array}{l}\text { The sky was partially } \\
\text { cloudy with sun } \\
\text { between clouds and } \\
\text { the flow of vehicles } \\
\text { on the BR } 104 \text { South } \\
\text { was normal. }\end{array}$ \\
\hline 9 & $\begin{array}{l}01 / 06 / 20 \\
16\end{array}$ & $\mathrm{~A} 1$ & $\begin{array}{l}33 \\
5\end{array}$ & $\begin{array}{l}29 . \\
5\end{array}$ & 57.6 & $\begin{array}{l}18 . \\
5\end{array}$ & $\begin{array}{l}21 . \\
3\end{array}$ & 43.4 & $532 \times 100$ & 1.4 & L & 4.9 & 959 & $\begin{array}{l}\text { The sky was partly } \\
\text { cloudy and the }\end{array}$ \\
\hline
\end{tabular}

power plant was functioning all the chimneys.

cloudy with sun between clouds and vehicles on the BR 104 South

The sky was partly cloudy and the thermoelectric functioning all the The sky was partially on the BR 104 South The sky was partly cloudy and the power plant was functioning all the The sky was partially cloudy with sun between clouds and on the BR 104 South was normal.

cloudy and the power plant was The sky was partially cloudy with sun ween clouds and on the BR 104 South as normal.

cloudy and the thermoelectric had five

The sky was partially the flow of vehicles on the BR 104 South The sky was partly cloudy and the power plant had five chimneys.

cloudy with sun between clouds and was normal.

cloudy and the 
$\begin{array}{clllllllllll}\text { A2 } & 33 & 29 . & 57.4 & 18 . & 21 . & 45.7 & 428 \times 100 & 2.3 & \text { L } & 5.3 & 959 \\ & 4 & 7 & & 7 & 5 & & & \end{array}$ 16

\begin{tabular}{|c|c|c|c|c|c|c|c|}
\hline A1 & 33 & 27. & 63 & 17. & 20. & 45.2 & $517 \times 100$ \\
\hline & 9 & 6 & & 4 & 6 & & \\
\hline & 33 & 27. & 62.5 & 17. & 20. & 45.9 & $418 \times 100$ \\
\hline & 7 & 8 & & 7 & 8 & & \\
\hline
\end{tabular}

$1101 / 28 / 20 \quad$ A1 $\quad 33 \quad 27 . \quad 61.5 \quad 17 . \quad 20 . \quad 44.5 \quad 488 \times 100$ 16

A2

3

8

12

A $33 \quad 28 . \quad 61.4 \quad$ 17. 20. $\quad 45.5 \quad 455 \times 100$

\begin{tabular}{|c|c|c|c|c|c|c|c|c|c|c|c|c|}
\hline \multirow{3}{*}{$\begin{array}{l}02 / 11 / 20 \\
16\end{array}$} & A1 & 32 & 26. & 65.3 & 16. & 19. & 43.7 & $473 \times 100$ & 1.1 & SE & 3.9 & 959 \\
\hline & & 5 & 7 & & 8 & 7 & & & & & & \\
\hline & A2 & $\begin{array}{l}32 \\
4\end{array}$ & $\begin{array}{l}27 . \\
2\end{array}$ & 65.1 & $\begin{array}{l}16 . \\
6\end{array}$ & $\begin{array}{l}19 . \\
4\end{array}$ & 45.7 & $422 \times 100$ & 2.6 & SE & 4.5 & 959 \\
\hline
\end{tabular}

$1302 / 24 / 20$ 16

\begin{tabular}{|c|c|c|c|c|c|c|c|}
\hline A1 & $\begin{array}{l}34 \\
2\end{array}$ & $\begin{array}{l}27 . \\
3\end{array}$ & 66.2 & $\begin{array}{l}17 . \\
1\end{array}$ & $\begin{array}{l}20 . \\
2\end{array}$ & 46.6 & $487 \times 100$ \\
\hline $\mathrm{A} 2$ & $\begin{array}{l}34 \\
1\end{array}$ & $\begin{array}{l}27 . \\
6\end{array}$ & 65.9 & $\begin{array}{l}17 . \\
5\end{array}$ & $\begin{array}{l}20 . \\
5\end{array}$ & 47.5 & 385 \\
\hline
\end{tabular}

$14 \quad 03 / 03 / 20 \quad$ A1 $36 \quad 24 . \quad 76.6 \quad 20 . \quad 20 . \quad 49.0 \quad 120 \times 100$ 16 $\begin{array}{lllllll}35 & 25 . & 76.1 & 21 & 20 . & 48 & 140 \times 100\end{array}$

$15 \quad 03 / 16 / 20 \quad$ A1 $36 \quad 23 . \quad 74.2 \quad 21 . \quad 22 . \quad 48.0 \quad 235 \times 100$ 16

$\begin{array}{lllllll}35 & 24 . & 72.1 & 22 & 22 . & 47.5 & 211 \times 100\end{array}$ 91

8

$04 / 06 / 20$ 16

$\begin{array}{llllllll}\text { A1 } & 35 & 26 . & 64 & 21 . & 23 . & 53.3 & 287 \times 100 \\ & 2 & 8 & & 6 & 2 & & \end{array}$

A2
$35 \quad 27.63$

$0 \quad 1$
21. 23. $46.1255 \times 100$ 84 $\begin{array}{llll}2.1 & \mathrm{~L} & 4.3 \quad 960\end{array}$

$2.4 \quad \mathrm{~L} \quad 5.1 \quad 960$

$\begin{array}{llll}2.6 & \mathrm{~L} & 4.3 & 958\end{array}$

$\begin{array}{llll}1.7 & \text { SE } & 4.2 \quad 960\end{array}$

$\begin{array}{llll}2.8 & \text { SE } & 4.9 & 960\end{array}$ $\begin{array}{llll}1.5 & \text { SE } & 2.7 & 958\end{array}$

$\begin{array}{llll}1.7 & \text { SE } & 3.7 & 961\end{array}$

$0.8 \quad$ SE $\quad 2.8 \quad 958$

$\begin{array}{llll}1.7 & \text { SE } & 3.5 & 961\end{array}$

1.7. SE $3.7 \quad 961$

1.8 SE 3.1958. 5 power plant was turned off.

The sky was partly cloudy and the flow of vehicles on the BR 104 South was normal.

The sky was partly cloudy and the power plant was turned off.

The sky was partly cloudy and the flow of vehicles on the $B R$ 104 South was normal.

The sky was partly cloudy and the power plant was off. The sky was partly cloudy and the flow of vehicles on the BR 104 South was normal.

The sky was partly cloudy and the power plant was off. The sky was partly cloudy and the flow of vehicles on the BR 104 South was normal.

The sky was partly cloudy and the power plant was off. The sky was partly cloudy and the flow of vehicles on the BR 104 South was normal.

The sky was cloudy and the thermoelectric power plant had five chimneys.

The sky was partly cloudy and the flow of vehicles on the $B R$ 104 Sul was normal.

The sky was cloudy and the thermoelectric power plant had five chimneys.

The sky was cloudy and the flow of vehicles on the $B R$ 104 South was normal.

The sky was partly cloudy and the thermoelectric power plant was operating 10 chimneys.

2.3 SE 4.5 958. The sky was partly cloudy and the flow 
17 16

A1 36

36

25.

77.5

20. 21

$380 \times 100$

A2

$\begin{array}{lllllll}35 & 28 . & 69.8 & 20 . & 22 . & 48.9 & 582 \times 100\end{array}$ 0

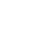
$04 / 20 / 2$
16

A1

37

2

$37 \quad 29 . \quad 67.2$ 27
19. $21 . \quad 54.6 \quad 252 \times 100$ 15
$2.1 \quad$ SE $\quad 4.3 \quad 959$

(2.1

$3.5 \quad$ SE $\quad 5.1 \quad 959$

$2.3 \quad$ SE $\quad 3.8 \quad 958$.

of vehicles on the $B R$

104 South was

normal.

The sky was partly cloudy and the thermoelectric power plant was operating 10 chimneys.

The sky was partly cloudy and the flow of vehicles on the BR 104 South was normal.

The sky was cloudy with occasional raindrops (sun between clouds) and the thermoelectric power plant was functioning only five chimneys.

$\begin{array}{llllllll}\text { A2 } & 35 & 26 . & 74.5 & 19 . & 21 . & 48.5 & 473 \times 100\end{array}$

3.2 SE 4.8 958. The sky was cloudy and the flow of vehicles on the $B R$ 104 South was normal.

$\begin{array}{llllllllllllll}19 & 04 / 27 / 20 & \text { A1 } & 35 & 25 . & 75.4 & 18 . & 20 . & 52.6 & 226 \times 100 & 2.3 & \text { SE } & 5.3 & 959\end{array}$ 16

$\begin{array}{llllll}\text { A1 } & 35 & 25 . & 75.4 & 18 . & 20 \\ & 4 & 5 & & 7 & 7\end{array}$

$$
\text { A2 }
$$
$35 \quad 27 . \quad 71.6$

19. 22

$39.9264 \times 100$

$3.2 \quad$ SE $\quad 5.4 \quad 959$ 17 84

$477 \times 100$

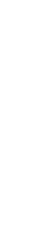

$\begin{array}{llllllll}\text { A2 } & 34 & 25 . & 72.5 & 18 . & 21 & 48.1 & 343 \times 100 \\ & 8 & 5 & & 2 & & & \end{array}$

$\begin{array}{llllllllll}21 & 05 / 11 / 20 & \text { A1 } & 36 & 25 . & 83.1 & 21 . & 23 . & 47.4 & 171 \times 100\end{array}$ 16

$\begin{array}{lll}A 1 & 36 & 25 \\ & 8 & 6\end{array}$

$$
6
$$

\author{
$\begin{array}{ll}\text { 9 } & \\ & \\ & \\ 18 . & 2 \\ 2\end{array}$
}

$\begin{array}{llll}2.7 & \mathrm{~S} & 5.5 & 960\end{array}$

$2.7-5$
$\mathrm{~S}-5$

The sky was partly cloudy and the thermoelectric power plant was operating 10 chimneys.

The sky was partly cloudy and the flow of vehicles on the BR 104 South was normal.

The sky was open with scattered clouds and the power plant was turned off. At the collection site, a faint smell of (oil) was also observed. The sky was open with scattered clouds and the flow of vehicles on the BR 104 South was normal.

$\begin{array}{llll}0.9 & S & 2.9 & 960\end{array}$

The sky was cloudy and rainy and the power plant was turned off. At the collection site, a faint smell of (oil) was also observed.

$\begin{array}{llllllllllll}\text { A2 } & 35 & 26 . & 82.4 & 21 . & 23 . & 46.1 & 166 \times 100 & 1.8 & \text { S } & 3.3 & 960 \\ & 7 & 3 & & 9 & 5 & & & & & & \end{array}$

$22 \quad 05 / 19 / 20 \quad$ A1 $\quad 35 \quad 23 . \quad 81.6 \quad 19 . \quad 20 . \quad 45.2 \quad 111 \times 100$ 16
$\begin{array}{llllllll}\mathrm{A} 1 & 35 & 23 . & 81.6 & 19 . & 20 . & 45.2 & 111 \times 100\end{array}$
The sky was cloudy and rainy and the flow of vehicles on the BR 104 South was normal.

The sky was partially cloudy with clouds of the Nimbostratus 


\begin{tabular}{|c|c|c|c|c|c|c|c|c|c|c|c|c|c|c|}
\hline & & $\mathrm{A} 2$ & $\begin{array}{l}35 \\
2\end{array}$ & $\begin{array}{l}24 . \\
3\end{array}$ & 79.0 & $\begin{array}{l}20 . \\
9\end{array}$ & $\begin{array}{l}22 . \\
6\end{array}$ & 43.8 & $420 \times 100$ & 2.7 & SE & 4.5 & 960 & $\begin{array}{l}\text { was turned off. } \\
\text { The sky was partly } \\
\text { cloudy and the flow } \\
\text { of vehicles on the BR }\end{array}$ \\
\hline & & & & & & & & & & & & & & $\begin{array}{l}104 \text { South was } \\
\text { normal. }\end{array}$ \\
\hline \multirow[t]{3}{*}{23} & $\begin{array}{l}05 / 27 / 20 \\
16\end{array}$ & $\mathrm{~A} 1$ & $\begin{array}{l}35 \\
8\end{array}$ & $\begin{array}{l}24 . \\
4\end{array}$ & 72.1 & $\begin{array}{l}21 . \\
1\end{array}$ & $\begin{array}{l}22 . \\
7\end{array}$ & 45.3 & $450 \times 100$ & 1.7 & so & 2.9 & 961 & $\begin{array}{l}\text { The sky was open } \\
\text { (sunny) and the } \\
\text { thermal power plant } \\
\text { was turned off. At } \\
\text { the collection site, a } \\
\text { faint smell of (oil) } \\
\text { was also observed. }\end{array}$ \\
\hline & & $\mathrm{A} 2$ & $\begin{array}{l}34 \\
4\end{array}$ & $\begin{array}{l}28 . \\
5\end{array}$ & 0.7 & $\begin{array}{l}19 . \\
8\end{array}$ & $\begin{array}{l}20 . \\
9\end{array}$ & 48.8 & $566 \times 100$ & 2.8 & so & 4.6 & 961 & $\begin{array}{l}\text { The sky was open } \\
\text { (sunny) and the flow } \\
\text { of vehicles on the BR }\end{array}$ \\
\hline & & & & & & & & & & & & & & $\begin{array}{l}104 \text { South was } \\
\text { normal. }\end{array}$ \\
\hline \multirow[t]{2}{*}{24} & $\begin{array}{l}06 / 01 / 20 \\
16\end{array}$ & $\mathrm{~A} 1$ & $\begin{array}{l}35 \\
7\end{array}$ & $\begin{array}{l}26 . \\
1\end{array}$ & 74.2 & $\begin{array}{l}20 . \\
9\end{array}$ & $\begin{array}{l}21 . \\
6\end{array}$ & 47.4 & $245 \times 100$ & 2.6 & SE & 5.1 & 959 & $\begin{array}{l}\text { The sky was sunny } \\
\text { with few clouds of } \\
\text { the altostratus and } \\
\text { altocumulus type } \\
\text { and the } \\
\text { thermoelectric } \\
\text { power plant was } \\
\text { turned off. }\end{array}$ \\
\hline & & A2 & $\begin{array}{l}34 \\
3\end{array}$ & $\begin{array}{l}28 . \\
4\end{array}$ & 69.3 & $\begin{array}{l}18 . \\
9\end{array}$ & $\begin{array}{l}20 . \\
8\end{array}$ & 47.7 & $633 \times 100$ & 3.3 & SE & 4.5 & 959 & $\begin{array}{l}\text { The sky was sunny } \\
\text { with few clouds and } \\
\text { the flow of vehicles } \\
\text { on the BR } 104 \text { South } \\
\text { was normal. }\end{array}$ \\
\hline 25 & $\begin{array}{l}06 / 08 / 20 \\
16\end{array}$ & $\mathrm{~A} 1$ & $\begin{array}{l}35 \\
8\end{array}$ & $\begin{array}{l}25 . \\
3\end{array}$ & 77.5 & $\begin{array}{l}20 . \\
1\end{array}$ & $\begin{array}{l}20 . \\
9\end{array}$ & 47.1 & $143 \times 100$ & 2.2 & L & 3.7 & 961 & $\begin{array}{l}\text { The sky was sunny } \\
\text { with few clouds of } \\
\text { the type altostratus } \\
\text { and altocumulus and } \\
\text { the thermoelectric } \\
\text { power plant was } \\
\text { turned off. }\end{array}$ \\
\hline & & $\mathrm{A} 2$ & $\begin{array}{l}34 \\
8\end{array}$ & $\begin{array}{l}27 . \\
5\end{array}$ & 71.0 & $\begin{array}{l}20 . \\
9\end{array}$ & $\begin{array}{l}23 . \\
1\end{array}$ & 46.7 & $190 \times 100$ & 3.5 & L & 4.3 & 961 & $\begin{array}{l}\text { The sky was sunny } \\
\text { with few clouds and } \\
\text { the flow of vehicles } \\
\text { on the BR } 104 \text { South } \\
\text { was normal. }\end{array}$ \\
\hline \multirow[t]{3}{*}{26} & $\begin{array}{l}06 / 15 / 20 \\
16\end{array}$ & $\mathrm{~A} 1$ & $\begin{array}{l}35 \\
3\end{array}$ & $\begin{array}{l}23 . \\
2\end{array}$ & 76.7 & $\begin{array}{l}18 . \\
6\end{array}$ & $\begin{array}{l}19 . \\
9\end{array}$ & 47 & $223 \times 100$ & 3.1 & L & 4.2 & 965 & $\begin{array}{l}\text { The sky was partially } \\
\text { cloudy and the } \\
\text { thermal power plant } \\
\text { was turned off. }\end{array}$ \\
\hline & & $\mathrm{A} 2$ & $\begin{array}{l}35 \\
2\end{array}$ & $\begin{array}{l}25 . \\
4\end{array}$ & 69.4 & $\begin{array}{l}16 . \\
7\end{array}$ & $\begin{array}{l}19 . \\
9\end{array}$ & 47.3 & $365 \times 100$ & 3.1 & L & 4.2 & 965 & $\begin{array}{l}\text { The sky was partly } \\
\text { cloudy and the flow } \\
\text { of vehicles on the BR }\end{array}$ \\
\hline & & & & & & & & & & & & & & $\begin{array}{l}104 \text { South was } \\
\text { normal. }\end{array}$ \\
\hline \multirow[t]{2}{*}{27} & $\begin{array}{l}06 / 22 / 20 \\
16\end{array}$ & $\mathrm{~A} 1$ & $\begin{array}{l}35 \\
9\end{array}$ & 24 & 83.3 & $\begin{array}{l}20 . \\
1\end{array}$ & $\begin{array}{l}20 . \\
2\end{array}$ & 45.2 & $154 \times 100$ & 2.4 & SE & 3.4 & 963 & $\begin{array}{l}\text { The sky was overcast } \\
\text { and the power plant } \\
\text { was off. }\end{array}$ \\
\hline & & $\mathrm{A} 2$ & $\begin{array}{l}35 \\
3\end{array}$ & 24 & 83.9 & $\begin{array}{l}20 . \\
3\end{array}$ & $\begin{array}{l}20 . \\
2\end{array}$ & 47.2 & $150 \times 100$ & 2.8 & SE & 3.7 & 963 & $\begin{array}{l}\text { The sky was cloudy } \\
\text { and the flow of } \\
\text { vehicles on the BR } \\
104 \text { South was } \\
\text { normal. }\end{array}$ \\
\hline 28 & $\begin{array}{l}06 / 30 / 20 \\
16\end{array}$ & $\mathrm{~A} 1$ & $\begin{array}{l}35 \\
3\end{array}$ & $\begin{array}{l}23 . \\
8\end{array}$ & 71.1 & $\begin{array}{l}17 . \\
9\end{array}$ & $\begin{array}{l}21 . \\
6\end{array}$ & 48.1 & $625 \times 100$ & 2.7 & $S$ & 5.4 & 962 & $\begin{array}{l}\text { The sky was open } \\
\text { with scattered } \\
\text { clouds and the } \\
\text { power plant was } \\
\text { turned off. }\end{array}$ \\
\hline
\end{tabular}

type and the thermal power plant was turned off. cloudy and the flow of vehicles on the BR 104 South was The sky was open (sunny) and the the collection site faint smell of (oil) The sky was open ) and the flow normal. the altostratus and thermoelectric power plant was The sky was sunny with few clouds and on the BR 104 South was normal.

with few clouds of the type altostratus the thermoelectric power plant was ped off. with few clouds and on the BR 104 South was normal. cloudy and the thermal power plant as turned off. cloudy and the flow icles on the BR 104 South was

The sky was overcast and the power plant The sky was cloudy normal.

with scattered clouds and the turned off. 
A2

3525

25.

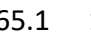

29 16

\section{A1}

35

35
5

22

A2 $\begin{array}{lllllll}35 & 25 & 69.1 & 17 . & 18 . & 46.1 & 211 \times 100\end{array}$ 1
7. 20

0.

$215 \times 100$

1

\begin{tabular}{|c|c|c|c|c|c|c|c|c|c|c|c|c|}
\hline \multirow[t]{2}{*}{$\begin{array}{l}07 / 104 / 2 \\
016\end{array}$} & A1 & $\begin{array}{l}35 \\
3\end{array}$ & $\begin{array}{l}23 \\
7\end{array}$ & 64.3 & $\begin{array}{l}17 . \\
9\end{array}$ & $\begin{array}{l}20 . \\
1\end{array}$ & 42.9 & $237 \times 100$ & 1.1 & $S$ & 2.1 & 961 \\
\hline & A2 & $\begin{array}{l}35 \\
2\end{array}$ & $\begin{array}{l}25 \\
4\end{array}$ & 69.2 & $\begin{array}{l}16 . \\
5\end{array}$ & 18. & 44.3 & $558 \times 100$ & 3.6 & $S$ & 5.7 & \\
\hline
\end{tabular}

$\begin{array}{lllllllll}07 / 20 / 20 & \text { A1 } & 35 & 23 . & 70 & 17 . & 19 . & 43.5 & 162 \times 100\end{array}$ 16

A2 35 23 75.2 17. $19.46 .5 \quad 79 \times 100$ $1.4 \quad$ SE $\quad 1.9 \quad 960$

1

32 $07 / 28 / 2$
16

A

A1 35
35 23.
3

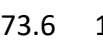

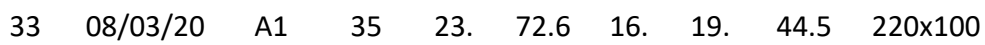
16

A2

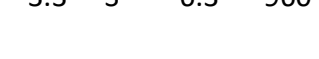

$\begin{array}{llll}1.1 & \text { SE } & 1.8 \quad 960\end{array}$
The sky was open with scattered clouds and the flow of vehicles on the BR 104 South was normal.

The sky was overcast and the power plant was off.

The sky was cloudy and the flow of vehicles on the $B R$ 104 South was normal.

The sky was overcast and the power plant was off.

The sky was cloudy and the flow of vehicles on the $B R$ 104 South was normal.

The sky was cloudy with occasional rain and the thermal power plant was turned off.

The sky was cloudy with occasional rain and the flow of vehicles on the $B R$ 104 South was normal.

The sky was partially cloudy sun between clouds and the thermal power plant was turned off.

The sky was partly cloudy and the flow of vehicles on the BR 104 South was normal.

The sky was partially cloudy sun between clouds and the thermal power plant was turned off.

The sky was partly cloudy and the flow of vehicles on the BR 104 South was normal.

The sky was cloudy and the power plant was turned off.

The sky was partially cloudy sun between clouds, thermal power was off.

The sky was cloudy the flow of vehicles on the BR 104 South was normal.

The sky was partly cloudy and the flow of vehicles on the BR 
$08 / 2$
A1

134

$34 \quad 24 . \quad 67.3$ 2 $\begin{array}{llll}4.7 & \text { SE } & 6.1 & 961\end{array}$

$2.5 \quad$ SE $\quad 6.1 \quad 962$

$37 \begin{array}{lllllllll}09 / 02 / 20 & \text { A1 } & 35 & 23 . & 74.0 & 17 . & 19 . & 45.6 & 226 \times 100\end{array}$ 16
3.6 $\quad$ SE $\quad 5.8 \quad 961$

16. $19.46 .5 \quad 486 \times 100$ $4 \quad 1$
4.2 SE $\quad 5.1 \quad 962$

$2.1 \quad$ SE $\quad 5.6 \quad 962$

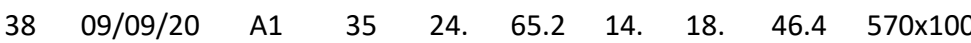
16

$\begin{array}{llllllll}\text { A2 } & 34 & 24 . & 69.4 & 17 . & 19 . & 48.5 & 135 \times 100\end{array}$

$4 \quad 1$

A2 34 8

26

60.5

17. 21

44

$574 \times 100$

$4.5 \quad S E$

6.9962

39$$
16
$$

16

$$
\begin{aligned}
& \text { A1 } 3 \\
& 35 \quad 24
\end{aligned}
$$

\begin{tabular}{|c|c|c|c|c|c|c|c|c|}
\hline \multirow{3}{*}{$\begin{array}{l}09 / 21 / 20 \\
16\end{array}$} & $\mathrm{~A} 1$ & 35 & 25. & 72.3 & 19. & 21. & 43.5 & $238 \times 100$ \\
\hline & & 4 & 4 & & 2 & 6 & & \\
\hline & A2 & 34 & 26. & 79.0 & 18. & 20. & 48.4 & $294 \times 100$ \\
\hline
\end{tabular}

$2.4 \quad S E$

40

$\begin{array}{llllllllll}41 & 09 / 29 / 20 & \text { A1 } & 35 & 24 . & 66.7 & 16 . & 18 . & 45.6 & 167 \times 100\end{array}$ 16

$\begin{array}{llllllll}\text { A1 } & 35 & 24 . & 66.7 & 16 . & 18 . & 45.6 & 167 \times 100 \\ & 4 & 7 & & 3 & 9 & & \\ & & & & & & & \\ & & & & & & & \\ \text { A2 } & 34 & 27 . & 58.0 & 16 . & 19 . & 47.7 & 633 \times 100 \\ & 6 & 9 & & 1 & 7 & & \end{array}$

$6 \quad$ SE $\quad 5.4 \quad 960$

$\begin{array}{llll}5.1 & \text { SE } & 6.6 & 960\end{array}$
104 South was normal.

The sky was scattered with clouds (sunny) and the thermal power plant was turned off. The sky was scattered with clouds (sunny) and the flow of vehicles on the BR 104 South was normal.

The sky was cloudy and rainy and the power plant was turned off.

The sky was cloudy and rainy and the flow of vehicles on the BR 104 South was normal.

The sky was scattered with clouds (sunny) and the thermal power plant was turned off.

The sky was scattered with clouds (sunny) and the flow of vehicles on the BR 104 South was normal.

The sky was scattered with clouds (sunny) and the thermal power plant was turned off. The sky was scattered with clouds (sunny) and the flow of vehicles on the BR 104 South was normal.

The sky was overcast and the power plant was off.

The sky was cloudy and the flow of vehicles on the $B R$ 104 South was normal.

The sky was overcast with rain clouds and the power plant was turned off.

The sky was partially cloudy with rain clouds and the flow of vehicles on the BR 104 South was normal.

The sky was partially cloudy and the thermal power plant was turned off.

The sky was partly 


\begin{tabular}{|c|c|c|c|c|c|c|c|c|c|c|c|c|c|c|}
\hline & & & 2 & 3 & & 6 & 2 & & & & & & & $\begin{array}{l}\text { cloudy and the flow } \\
\text { of vehicles on the BR }\end{array}$ \\
\hline & & & & & & & & & & & & & & $\begin{array}{l}104 \text { South was } \\
\text { normal. }\end{array}$ \\
\hline \multirow[t]{4}{*}{43} & $11 / 17 / 20$ & A1 & 35 & 26. & 70.5 & 19. & 21. & 48.6 & $465 \times 100$ & 2.6 & L & 5.6 & 957 & The sky was cloudy \\
\hline & 16 & & 1 & 5 & & 1 & 6 & & & & & & & $\begin{array}{l}\text { sun between clouds } \\
\text { and the } \\
\text { thermoelectric } \\
\text { power plant had five } \\
\text { chimneys } \\
\text { connected. }\end{array}$ \\
\hline & & $A 2$ & 34 & 29. & 59.9 & 18. & 21. & 49.7 & $146 \times 100$ & 3.2 & L & 7.5 & 957 & The sky was cloudy \\
\hline & & & 9 & 3 & & 6 & 1 & & & & & & & $\begin{array}{l}\text { sun between clouds } \\
\text { and the flow of } \\
\text { vehicles on the BR } \\
104 \text { South was } \\
\text { normal. }\end{array}$ \\
\hline \multirow[t]{5}{*}{44} & $11 / 24 / 20$ & A1 & 35 & 25. & 66.3 & 19. & 20. & 45.4 & $492 \times 100$ & 2.2 & L & 4.2 & 960 & The sky was cloudy \\
\hline & 16 & & 5 & 8 & & 9 & 6 & & & & & & & $\begin{array}{l}\text { sun between clouds } \\
\text { and the thermal } \\
\text { power plant was } \\
\text { turned off. }\end{array}$ \\
\hline & & A2 & 34 & 28 & 60.5 & 17. & 20. & 47.3 & $294 \times 100$ & 3.3 & L & 6.4 & 960 & The sky was partially \\
\hline & & & 2 & & & 4 & 1 & & & & & & & $\begin{array}{l}\text { cloudy sun between } \\
\text { clouds and the flow } \\
\text { of vehicles on the BR }\end{array}$ \\
\hline & & & & & & & & & & & & & & $\begin{array}{l}104 \text { South was } \\
\text { normal. }\end{array}$ \\
\hline \multirow[t]{5}{*}{45} & $12 / 01 / 20$ & A1 & 34 & 27. & 64.6 & 18 & 20. & 45.9 & $159 \times 100$ & 2.1 & L & 3.4 & 959 & The sky was cloudy \\
\hline & 16 & & 7 & 4 & & & 8 & & & & & & & $\begin{array}{l}\text { sun between clouds } \\
\text { and the thermal } \\
\text { power plant was } \\
\text { turned off. }\end{array}$ \\
\hline & & A2 & 34 & 28. & 58.4 & 16. & 19. & 49.9 & $184 \times 100$ & 4.5 & $\mathrm{~L}$ & 6.1 & 959 & The sky was partially \\
\hline & & & 2 & 3 & & 5 & 6 & & & & & & & $\begin{array}{l}\text { cloudy sun between } \\
\text { clouds and the flow } \\
\text { of vehicles on the BR }\end{array}$ \\
\hline & & & & & & & & & & & & & & $\begin{array}{l}104 \text { South was } \\
\text { normal. }\end{array}$ \\
\hline \multirow[t]{4}{*}{46} & $12 / 15 / 20$ & A1 & 35 & 28 & 63.8 & 17. & 20. & 47.2 & $328 \times 100$ & 1.5 & SE & 5.1 & 959 & The sky was cloudy, \\
\hline & 16 & & 2 & & & 3 & 2 & & & & & & & $\begin{array}{l}\text { subject to rain and } \\
\text { the thermal power } \\
\text { plant was turned off. }\end{array}$ \\
\hline & & A2 & 34 & 28. & 62.6 & 18. & 21. & 44.6 & $183 \times 100$ & 4.8 & SE & 6.8 & 959 & The sky was cloudy \\
\hline & & & 3 & 6 & & 8 & 6 & & & & & & & $\begin{array}{l}\text { and subject to rain } \\
\text { and the flow of } \\
\text { vehicles on the BR } \\
104 \text { South was } \\
\text { normal. }\end{array}$ \\
\hline \multirow[t]{5}{*}{47} & $01 / 19 / 20$ & A1 & 34 & 26. & 65 & 17. & 21. & 44.5 & $525 \times 100$ & 1.8 & SE & 5.4 & 958 & The sky was partly \\
\hline & 17 & & 9 & 7 & & 1 & 2 & & & & & & & $\begin{array}{l}\text { cloudy and the } \\
\text { power plant was } \\
\text { turned off. }\end{array}$ \\
\hline & & A2 & 34 & 28. & 58.3 & 16. & 20. & 45.4 & $615 \times 100$ & 1.5 & SE & 4.6 & 958 & The sky was partially \\
\hline & & & 8 & 9 & & 1 & 4 & & & & & & & $\begin{array}{l}\text { cloudy and the flow } \\
\text { of vehicles on the BR }\end{array}$ \\
\hline & & & & & & & & & & & & & & $\begin{array}{l}104 \text { South was } \\
\text { normal. }\end{array}$ \\
\hline \multirow[t]{5}{*}{48} & $01 / 25 / 20$ & A1 & 35 & 27 & 64.1 & 17. & 20. & 46.1 & $421 \times 100$ & 1.3 & L & 4.6 & 969. & The sky was partly \\
\hline & 17 & & 1 & & & 1 & 1 & & & & & & 7 & $\begin{array}{l}\text { cloudy and the } \\
\text { power plant was } \\
\text { turned off. }\end{array}$ \\
\hline & & $A 2$ & 34 & 29. & 56.8 & 16. & 19. & 43.4 & $313 \times 100$ & 5 & $\mathrm{~L}$ & 7.6 & 969. & The sky was partially \\
\hline & & & 8 & 7 & & 9 & 6 & & & & & & 7 & $\begin{array}{l}\text { cloudy and the flow } \\
\text { of vehicles on the BR }\end{array}$ \\
\hline & & & & & & & & & & & & & & $\begin{array}{l}104 \text { South was } \\
\text { normal. }\end{array}$ \\
\hline
\end{tabular}


$\begin{array}{llllllllllllllll} & 02 / 02 / 20 & \text { A } 1 & 35 & 28 & 67.9 & 18 & 20 & 56.6 & 328 \times 100 & 1.1 & \text { L } & 4.4 & 958 & \text { The sky } & \text { was partly }\end{array}$ $\begin{array}{lllllllll}17 & 3 & 1 & 8 & 7 & \text { cloudy and the }\end{array}$ thermoelectric power plant was operating with two

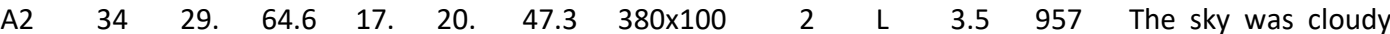
$6292 \quad 2 \quad$ and the flow of vehicles on the $\mathrm{BR}$ 104 South was normal.

$\begin{array}{llllllllllllll}50 & 02 / 09 / 20 & \text { A1 } & 35 & 27 . & 69.3 & 18 . & 21 . & 54.1 & 262 \times 100 & 1.3 & \text { L } & 4.1 & 957 .\end{array}$

The sky was partly 17 3218

5

cloudy and the thermoelectric power plant was operating with 10 chimneys.

$\begin{array}{lllllllllllll}\text { A2 } & 34 & 27 . & 67.5 & 18 . & 22 . & 46.6 & 223 \times 100 & 1.4 & \mathrm{~L} & 4.8 & 957 & \text { The sky was cloudy }\end{array}$ and the flow of vehicles on the $B R$ 104 South was normal.

$\begin{array}{lllllllllllllll}51 & 02 / 16 / 20 & \text { A } 1 & 34 & 26 . & 66.4 & 17 . & 20 . & 47.1 & 194 \times 100 & 1.2 & \text { SE } & 2.5 & 959 & \text { The sky was cloudy }\end{array}$ $\begin{array}{lllllll}17 & 7 & 2 & 6 & 2 & \end{array}$ and the thermoelectric was off.

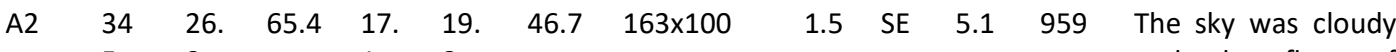
and the flow of vehicles on the BR 104 South was normal.

$\begin{array}{lllllllllllllll}52 & 02 / 22 / 20 & \text { A1 } & 35 & 25 & 70.1 & 18 . & 20 . & 47.6 & 215 \times 100 & 1.2 & \mathrm{~L} & 4.2 & 957 . & \text { The sky }\end{array}$ 17

$$
\begin{array}{llllllll} 
& 2 & 1 & & 1 & 5 & & \\
\mathrm{~A} 2 & 34 & 26 . & 68.9 & 19 . & 21 . & 47.8 & 185 \times 100 \\
& 8 & 2 & & 2 & 6 & &
\end{array}
$$

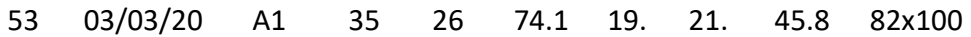
17

15

5

$$
\begin{array}{llllllll}
\text { A2 } & 35 & 27 . & 64.6 & 17 . & 20 . & 47.1 & 130 \times 100 \\
& 4 & 6 & & 4 & 2 & &
\end{array}
$$

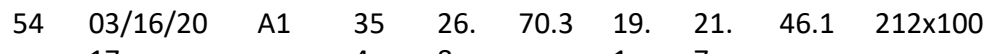
17

$0.9 \quad$ SE $\quad 1.8 \quad 958$

$2.4 \quad$ SE $\quad 5.1 \quad 958$

$2.5 \quad$ SE $\quad 4.7 \quad 957$ 17

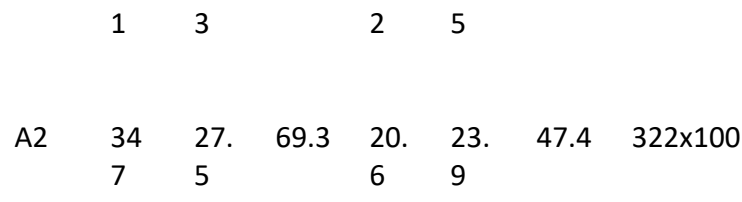

$\begin{array}{llllllll}\text { A } 1 & 35 & 26 . & 89.8 & 22 . & 23 . & 49.3 & 83 \times 100\end{array}$ and

thermoelectric was off.

$\begin{array}{lllll}1.3 & \mathrm{~L} & 4.8 & 957 . & \text { The sky was cloudy }\end{array}$ and the flow of vehicles on the $B R$ 104 Sul was normal.

2.5 S 4 958. The sky was cloudy and the thermoelectric was off.

The sky was cloudy and the flow of vehicles on the $B R$ 104 South was normal.

The sky was partly cloudy and thermoelectric was off.

The sky was partially cloudy and the flow of vehicles on the $B R$ 104 South was normal.

Partly cloudy skies and the thermoelectric was off.

$\begin{array}{lllll}2.3 & \text { SE } & 5.4 & 957 & \text { The sky was partially }\end{array}$ cloudy and the flow of vehicles on the BR 104 South was normal.

1.8 SE $3.4 \quad 958$. The cloudy sky and 

power plant had five connected

$\begin{array}{llllllll}\text { A2 } & 34 & 26 . & 89.8 & 22 . & 23 . & 47.5 & 101 \times 100 \\ & 9 & 9 & & 2 & 3 & & \end{array}$

1.9 SE $\quad 4.8 \quad 958$. 2 chimneys.

The sky was cloudy and the flow of vehicles on the $B R$ 104 South was normal.

Note: $\mathrm{CO}_{2}=$ Carbon dioxide $(\mathrm{ppm}) ; \mathrm{T}=$ Temperature $\left({ }^{\circ} \mathrm{C}\right) ; \mathrm{RH}=$ Relative Humidity (\%); DPT = Dew Point Temperature $\left({ }^{\circ} \mathrm{C}\right)$; WBT = Wet Bulb Temperature $\left({ }^{\circ} \mathrm{C}\right) ; \mathrm{dB}=$ Decibels; Lux = Luminescence; Vel. = Velocity $(\mathrm{m} / \mathrm{s}) ;$ Gust = Gust $(\mathrm{m} / \mathrm{s}) ; \mathrm{P}=$ Absolute pressure $(\mathrm{hPa})$.

Table 2 corresponds to the eigenvalues that reflect the quality of the projection of the initial dimension table, where the first value is equal to 3,371 and the second is equal to 2,197 , thus representing $42,84 \%$ of the total variability.

Table 2: Principal Component Analysis, classification of eigenvalues and corresponding factors, in descending order. 2017

\begin{tabular}{|c|c|c|c|c|c|c|c|c|c|c|c|c|c|}
\hline & F1 & F2 & F3 & F4 & F5 & F6 & F7 & F8 & F9 & F10 & F11 & F12 & F13 \\
\hline Self-values & 3.371 & 2.197 & 1.625 & 1.268 & 1.177 & 0.908 & 0.704 & 0.533 & 0.392 & 0.311 & 0.224 & 0.172 & 0.118 \\
\hline Variability & 25.93 & 16.90 & 12.50 & & & & & & & & & & \\
\hline $\begin{array}{l}\text { (\%) } \\
\%\end{array}$ & 2 & 3 & 4 & 9.752 & 9.057 & 6.985 & 5.413 & 4.097 & 3.016 & 2.389 & 1.723 & 1.320 & 0.909 \\
\hline accumulat & 25.93 & 42.83 & 55.33 & 65.09 & 74.14 & 81.13 & 86.54 & 90.64 & 93.65 & 96.04 & 97.77 & 99.09 & 100.00 \\
\hline ed & $\begin{array}{l}2 \\
F 1\end{array}$ & $\begin{array}{l}5 \\
F 2\end{array}$ & $\begin{array}{l}9 \\
\text { F3 }\end{array}$ & $\begin{array}{l}1 \\
F 4\end{array}$ & $\begin{array}{l}8 \\
\text { F5 }\end{array}$ & $\begin{array}{l}3 \\
\text { F6 }\end{array}$ & $\begin{array}{l}6 \\
\text { F7 }\end{array}$ & $\begin{array}{l}3 \\
F 8\end{array}$ & $\begin{array}{l}9 \\
\text { F9 }\end{array}$ & $\begin{array}{l}9 \\
\text { F10 }\end{array}$ & $\begin{array}{l}2 \\
F 11\end{array}$ & $\begin{array}{l}1 \\
F 12\end{array}$ & $\begin{array}{l}0 \\
\text { F13 }\end{array}$ \\
\hline
\end{tabular}

With the data present in table 3 , it was possible to create a map of the circle of correlations with projection of the initial variables in the factorial space shown in Figure 5.

Table 3: Correlations between variables and factors. 2017

\begin{tabular}{|c|c|c|c|c|c|c|c|c|c|c|c|c|c|}
\hline & F1 & F2 & F3 & F4 & F5 & F6 & F7 & F8 & F9 & F10 & F11 & F12 & F13 \\
\hline & & - & & - & & & & - & & - & & & \\
\hline \multirow[t]{2}{*}{ Date } & 0.193 & 0.285 & 0.416 & 0.524 & 0.006 & 0.583 & 0.149 & 0.018 & 0.198 & 0.154 & 0.021 & 0.075 & 0.034 \\
\hline & - & - & & & & - & - & & & & - & - & \\
\hline \multirow[t]{2}{*}{ Areas } & 0.482 & 0.042 & 0.629 & 0.144 & 0.054 & 0.157 & 0.392 & 0.254 & 0.300 & 0.035 & 0.087 & 0.058 & 0.042 \\
\hline & & - & & & & & & & & & & - & - \\
\hline \multirow[t]{2}{*}{$\mathrm{CO}_{2}$} & 0.720 & 0.144 & 0.053 & 0.406 & 0.044 & 0.279 & 0.175 & 0.013 & 0.164 & 0.396 & 0.000 & 0.013 & 0.009 \\
\hline & - & & & - & & & & & - & & & - & - \\
\hline \multirow[t]{2}{*}{$T$} & 0.602 & 0.567 & 0.178 & 0.279 & 0.080 & 0.157 & 0.179 & 0.209 & 0.068 & 0.122 & 0.193 & 0.181 & 0.103 \\
\hline & & - & & & - & - & & - & & - & & - & - \\
\hline \multirow[t]{2}{*}{ RH } & 0.672 & 0.099 & 0.216 & 0.180 & 0.542 & 0.175 & 0.015 & 0.156 & 0.143 & 0.173 & 0.153 & 0.179 & 0.067 \\
\hline & & & & & & - & & & - & 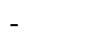 & & - & \\
\hline \multirow[t]{2}{*}{ DPT } & 0.585 & 0.425 & 0.509 & 0.096 & 0.272 & 0.162 & 0.140 & 0.028 & 0.167 & 0.043 & 0.104 & 0.010 & 0.218 \\
\hline & & & & & & - & & - & & - & - & & - \\
\hline \multirow[t]{2}{*}{ WBT } & 0.301 & 0.769 & 0.297 & 0.211 & 0.185 & 0.062 & 0.225 & 0.009 & 0.081 & 0.136 & 0.187 & 0.094 & 0.163 \\
\hline & & & - & & - & & - & & - & - & & - & \\
\hline \multirow[t]{2}{*}{$\mathrm{dB}$} & 0.095 & 0.398 & 0.427 & 0.480 & 0.176 & 0.479 & 0.171 & 0.306 & 0.017 & 0.180 & 0.025 & 0.013 & 0.056 \\
\hline & - & & - & & & - & & - & & - & & - & \\
\hline \multirow[t]{2}{*}{ Lux } & 0.623 & 0.259 & 0.439 & 0.141 & 0.193 & 0.123 & 0.288 & 0.186 & 0.377 & 0.054 & 0.084 & 0.009 & 0.100 \\
\hline & - & - & & & - & & & 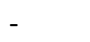 & - & - & & & - \\
\hline \multirow[t]{2}{*}{ Vel } & 0.636 & 0.279 & 0.396 & 0.491 & 0.074 & 0.040 & 0.044 & 0.053 & 0.082 & 0.020 & 0.228 & 0.212 & 0.060 \\
\hline & & - & - & & & & - & - & - & - & & - & - \\
\hline \multirow[t]{2}{*}{ Dir } & 0.188 & 0.378 & 0.037 & 0.212 & 0.806 & 0.146 & 0.200 & 0.149 & 0.026 & 0.124 & 0.062 & 0.129 & 0.076 \\
\hline & - & - & & & - & & & - & - & - & - & - & \\
\hline Gust & 0.706 & 0.094 & 0.305 & 0.301 & 0.185 & 0.272 & 0.176 & 0.273 & 0.161 & 0.012 & 0.205 & 0.156 & 0.059 \\
\hline Atmospheric & - & - & - & & & - & & & - & - & - & - & - \\
\hline pressure & 0.023 & 0.731 & 0.051 & 0.130 & 0.083 & 0.195 & 0.458 & 0.413 & 0.022 & 0.114 & 0.061 & 0.051 & 0.008 \\
\hline
\end{tabular}

Regarding the contribution of variables in the main components, it can be seen in the analysis of the 
map of the circle of correlations (Figure 5), where it is evident that the variables $\mathrm{RH}$ and $\mathrm{CO}_{2}$ are positively correlated, being negatively correlated in relation to the variables Vel., Gust and Areas, and orthogonal pressure variables Atm, dB and WBT. Another important fact is that all variables are removed from the circle of correlations on the factorial map, this shows that all variables have little contribution.

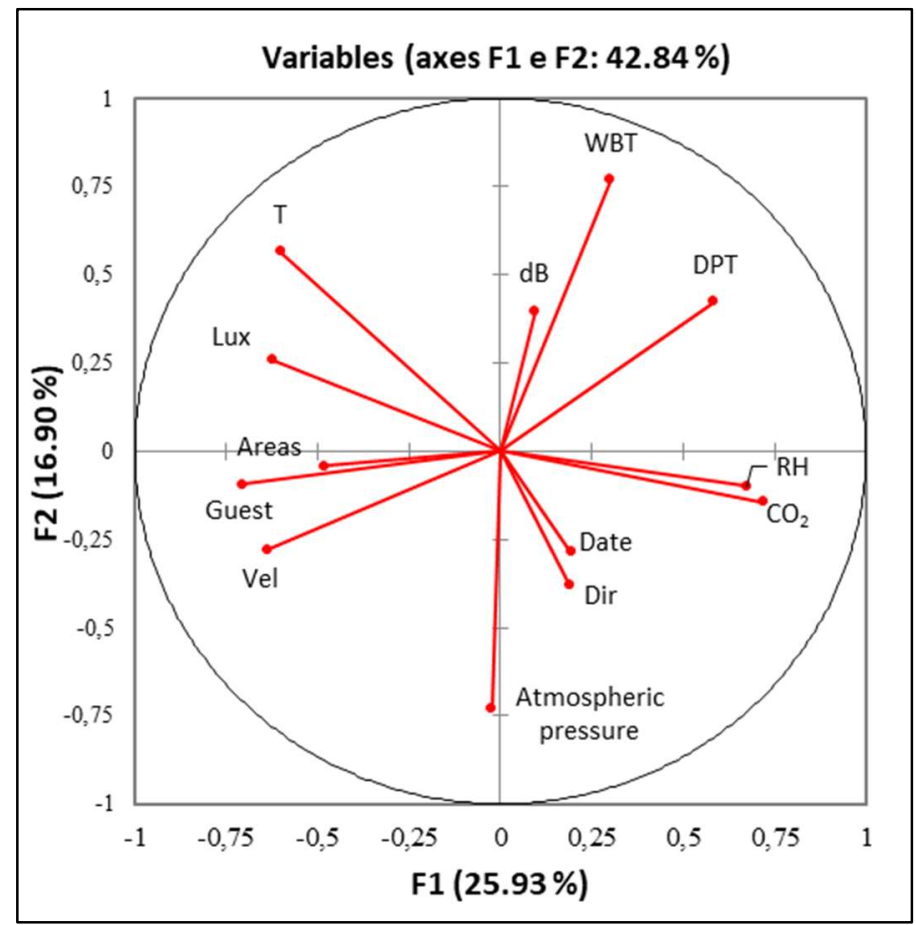

Figure 5: Map of the circle of correlations with projection of the initial variables in the factorial space.

Principal component analysis (PCA) is used to reduce the dimensions of the original variables without loss of information. By definition, the correlation between the main components is zero, and the variation explained in the main component (MC) MC1 is independent of the variation explained in $M C 2$, and so on. Therefore, any major component will not cause a correlated response in terms of other orthogonal components (SAVEGNAGO et al., 2011; FRAGA et al., 2015).

In this context, according to Vicini (2005), in the analysis of the circle of correlations, the vectors that represent variable points of high contribution are extremes close to the circumference of the circle of correlations in the factorial map, thus representing the variables that justify the greatest dispersion. These being the variables that play a more relevant role in the analysis, as they are the determining variables of the main component.

Differing from our data using multivariate statistics applied to the study of air quality in the city of Rio de Janeiro, Leoni et al. (2017), found in the environmental variables the existence of a high correlation, thus helping to understand the interrelationship of environmental variables in a synergy between the chemistry of the atmosphere and the statistical tools.

About the efficiency of the Portable Multifunctional Meter Model ITMCO2-600 in the measurement of carbon dioxide in the two study areas, it was confirmed that it was efficient, and it is believed that the non-discrepancy between the areas surveyed was due to the little or inexpressive activity of the Borborema S.A. thermal power plant, in addition to the distance from the emitting source, where the data were recorded 
at more than $100 \mathrm{~m}$, and height above $35 \mathrm{~m}$ from the ground, thus dispersing the gases produced by the TPP. In this sense, justifying the efficiency of the portable environmental sensors, it was verified by Silva et al (2013a), concentrations of gases and climatic conditions inside the Cave (SD-32) of Lapa do Sufoco, in São Desidério-BA, using a portable $\mathrm{CO}_{2}$ meter, (meter similar to the ITMCO $2-600$ model), where they verified that the values for $\mathrm{CO}_{2}$ varied between 926 and 1,423ppm throughout the cave, thus demonstrating high sensitivity in the use of this type of sensor.

According to Metz et al. (2007), in the last three decades, emissions of all greenhouse gases increased by an average of $1,6 \%$ per year, while $\mathrm{CO}_{2}$ emissions from fossil fuels increased by $1,9 \%$ per year $\mathrm{CO}_{2}$ concentrations increased by almost 100ppm compared to their pre-industrial level, reaching 379ppm in 2005, with average annual growth rates in the 2000-2005 period that were higher than the 1990's.

Therefore, the total $\mathrm{CO}_{2}$ equivalent $\left(\mathrm{CO}_{2}\right.$-eq) of all long-lived Greenhouse Gases (GHG) is currently estimated at around $455 \mathrm{ppm} \mathrm{CO}_{2}$-eq, although the effect of Aerosols, other air pollutants, and changes in land use reduce the net effect by levels ranging from 311 to $435 \mathrm{ppm}$ of $\mathrm{CO}_{2}$-eq (METZ et al., 2007). It should also be noted that by stoichiometric calculation, $1 \mathrm{~kg}$ of carbon produces $3,67 \mathrm{~kg}$ of carbon dioxide (MCTIC, 2006).

Regarding the global efficiency of thermal power plants, it is an important parameter that is directly related to the amount of fuel that is burned in relation to the amount of energy generated. In this way, the efficiency of these plants in terms of $\mathrm{CO}_{2}$ emissions, can be assessed by means of a carbon emission factor such as the amount of $\mathrm{CO}_{2}$ emitted in the combustion process in relation to the energy generated (LICKS et al., 2010).

Among the climatic factors that influence a given region, Nayak et al. (2006) highlight the waterproofing and occupation of the soil by concrete constructions, deforestation, pollution of the atmosphere and water courses, and the production of heat generate several effects on aspects of the environment. Therefore, the density of the built environment, the extent of tree cover, the type of vegetation, pollution and heat from vehicle traffic, industrialization and human activities are factors that affect the intensity of heat islands in cities, the process this more accentuated in the big cities.

Thus, according to Sousa et al. (2011) the average annual air temperature in Campina Grande-PB showed an increasing trend, quite accentuated during the period from 1963 to 2004, in all months of the year. The period of intense post-urbanization (POST-UI) was warmer than in the intense pre-urbanization (PRE-UI), with the average temperature of all months in the POST-UI period being around $1^{\circ} \mathrm{C}$ higher, with an abrupt climatological average. in the 80 's.

Thus, air pollution is another problem that interferes with climatic factors, as it gets worse with dry air, as well as occurs in phenomena such as thermal inversion. According to the World Health Organization (WHO), the ideal values of relative humidity are in the range of $40 \%$ to $70 \%$. Because the water vapor content contained in the air has a direct influence on human health, where the low relative humidity of the air alters the balance of the respiratory system, providing a risk to the integrity of the airway (SILVA JÚNIOR et al., 2011). 
Atmospheric humidity also directly influences the risk of forest fire. There is a constant exchange of water vapor between the atmosphere and the material deposited on the ground. For example, in a natural environment that in conditions of very dry atmosphere can even favor the reduction of moisture in living vegetation, making it more prone to combustion (MARIN et al., 2008).

As for the plume that leaves the chimneys of the thermoelectric plants, it is observed that they rise according to their temperature, the ambient temperature (whose difference causes thrust) and the outlet speed, and when released into the atmosphere, it suffers a dispersion effect according to parameters meteorological conditions, such as wind speed and direction, temperature, atmospheric stability, among others. Resulting in a process of advection by medium wind (which transports where the wind is blowing) and turbulent diffusion through the horizontal and vertical opening of the plume (ENVEX et al., 2009).

Among other factors arising from industrial activities, noise stands out, which is an inevitable residue resulting from practically all industrial activities that affect the environment and the neighborhood in general. In order to guarantee the conditions required for assessing the acceptability of noise in communities, regardless of the existence of complaints, it was standardized by the Brazilian Association of Technical Standards-NBR 10151/2000, that the noise levels in areas inhabited for outdoor environments must fit according to table 4.

Table 4: Level of noise evaluation criteria, for outdoor environments, in dB (A). 2017

\begin{tabular}{lll}
\hline Types of areas & Daytime & Night \\
\hline Rural areas and farms & 40 & 35 \\
Strictly urban residential area or hospitals or schools & 50 & 45 \\
Mixed, predominantly residential area & 55 & 50 \\
Mixed area - commercial and administrative & 60 & 55 \\
Mixed area - recreational & 65 & 55 \\
Predominantly industrial area & 70 & 60 \\
\hline
\end{tabular}

Source: NBR 10151/2000.

In this sense, it is observed that at the Borborema S.A. thermal power plant is located in the municipality of Queimadas-PB, in a peri-urban area close to the community of Ligeiro and the Velame district of Campina Grande-PB, with emphasis on residences that are up to $350 \mathrm{~m}$ from TPP. Contrary to this, what establishes the resolutions and regulations for Brazilian noise control, since in full operation (with the turbines and generators turned on) it was registered with the Multifunctional Portable Meter model ITMP600 values greater than $66 \mathrm{~dB}$, at a distance about $200 \mathrm{~m}$ from the TPP. It is also discussed that Consultoria Ambiental Ltda. during the preparation of the Environmental Impact Study-EIS/Environmental Impact Report- EIR/2008, it neglected the residences surrounding the TPP, only presenting noise records (within the limits of the standard) in more distant areas of the thermoelectric power plant.

Thus, it appears that the data related to the predominance of the wind direction, other studies point out different results to this study, because according to Silva et al. (2002) in the city of Campina Grande-PB, the predominant wind direction is from the East, with variation to the Southeast. Following this same trend Lima et al. (2010) also address in the study carried out on wind potential in Paraíba, with reference period 1977 to 1981 , that the predominance of the wind direction is in the East, with a variation of $45^{\circ}$ to $135^{\circ}$ (Northeast to Southeast). Still, it was observed that in the municipalities of Campina Grande and João Pessoa 
there was a decrease in the winds during the night due to the influence of terrestrial breezes in the opposite direction to large-scale runoff.

And in relation to atmospheric pressure it appears that it occurs with different intensities in different regions of the planet, these differences being responsible for the interference in the behavior of the climate. In this context, according to Sousa Júnior (2006), the intra-annual variability of atmospheric pressure in the city of Campina Grande-PB, in the period from 1963 to 2004, suffered a variation of around 15\%, with maximum values of $21 \%$.

\section{CONCLUSIONS}

It is concluded that considering that the Borborema S.A. thermal power plant only worked a few times during the period of this study, the data recorded through the environmental sensors were not significant among the areas surveyed, regarding the values of $\mathrm{CO}, \mathrm{CO}_{2}, \mathrm{SO}_{2}$, air temperature, relative humidity, dew point temperature, and luminescence.

Regarding the wind speed, the two areas showed little variation. The noise levels in area 1, on the other hand, when the thermoelectric plant was fully operational increased above the permitted level, in accordance with current Brazilian regulations. Thus, impairing the health of the residents who live in the surrounding area during the operation of the TPP, in addition to damaging the surrounding fauna, especially the birds that are driven away by the noise, and, consequently, reducing the diversity of avifauna surrounding the Thermal Power Plant.

Thus, the use of environmental sensors to monitor the air quality of this area is very important, as it will make it possible to verify changes in the environment around the Thermoelectric plant, in addition to representing qualitatively and quantitatively, through values and scales, the current environmental conditions, and serving in this way as a comparative support to future studies, as well as instituting the genesis for an environmental database of this metropolitan region of Campina Grande-PB.

It was not possible to link other changes and environmental disturbances, and to the health of the population in the surrounding and surrounding areas, given that the Borborema S.A. thermal power plant only functioned in the period surveyed, at the request of ANEEL, when the Red Flag was generated for generation of electricity.

Thus, there is a need to carry out other specific studies, including, if necessary, the use of other methodologies, in order to deepen these results. In this sense, it is necessary to constantly monitor and record pollutant gas emissions by the Borborema S.A. thermal power plant; intervention by the competent environmental agencies, in order to resolve the issue of noise emissions outside the established acceptable standards (a fact that occurs when the TPP is in full operation).

ACKNOWLEDGMENTS: This work was supported by CNPQ (National Council of Technology and Scientific Development) through the doctoral scholarship. 


\section{REFERENCES}

ABNT. Associação Brasileira de Normas Técnicas. NBR 10151: Acústica: Avaliação do ruído em áreas habitadas, visando o conforto da comunidade: Procedimento. Rio de Janeiro: ABNT, 2000

AMARAL, G. D.; SILVA, V. L.; REIS, E. A.. Análise de Regressão Linear no Pacote R. Relatório Técnico Série Ensino RTE 001. Belo Horizonte: UFMG, 2009.

ANEEL. Agência Nacional de Energia Elétrica. Bandeiras Tarifárias. ANEEL, 2015.

ANEEL. Agência Nacional de Energia Elétrica. Informações gerenciais de março 2019. ANEEL, 2019.

ATĂNĂSOAE, M.. The thermo-electric power plants and the environment. the impact of t.p.p. suceava on the environment: case study. Analele Universităţii "Ştefan cel Mare" Suceava, Secţiunea Geografie, v.18, p.217-224, 2009.

CAL. Consultoria Ambiental Ltda. Estudo de impacto ambiental e relatório de Impacto ambiental: EIA/RIMA, na Usina Termelétrica Borborema S.A. Campina Grande: CAL, 2008.

CHEVRON. Diesel Fuel and Air Quality. San Ramon: Chevron Corporation, 2004.

COLOSSI, B. R.. Avaliação ambiental de uma usina termoelétrica a óleo combustível utilizando análise do ciclo de vida. Porto Alegre: UFRGS, 2012.

CONAMA. Conselho Nacional do Meio Ambiente. Resolução n. 003, de 28 de junho de 1990. Brasília: MMA, 1990.

DRUMM, F. C. GERHARDT, A. E.; FERNANDES, G. D.; CHAGAS, P.; SUCOLOTTI, M. S. KEMERICH, P. D. C.. Poluição atmosférica proveniente da queima de combustíveis derivados do petróleo em veículos automotores. Revista Eletrônica em Gestão, Educação e Tecnologia Ambiental, v.18, n.1, p.66-78, 2014. DOI:

http://dx.doi.org/10.5902/2236117010537

ENVEX; SIMILAR. Engenharia e Consultoria Ambiental; Controle de Emissões Atmosféricas. Estudo da dispersão atmosférica de poluentes, utilizando o modelo ISCST3 (Industrial Source Complex) para a usina termoelétrica de Agudos do Sul (município de Agudos do Sul/PR). Curitiba: ENVEX, 2009.

FEEMA. Fundação Estadual de Engenharia do Meio Ambiente. Inventário de Fontes Emissoras de Poluentes Atmosféricos da Região Metropolitana do Rio de Janeiro. Rio de Janeiro: FEEMA, 2004.

FRAGA, A. B.; SILVA, F. L.; HONGYU, K.; SANTOS, D. S.; MURPHY, T. W.; LOPES, F. B.. Multivariate analysis to evaluate genetic groups and productiontraits of crossbred Holstein $\times$ Zebu cows. Trop Anim Health Prod., v.48, p.533538. 2015. DOI: http://dx.doi.org/10.1007/s11250-0150985-2

GALVÃO, I. J.; BERMANN, C.. Crise hídrica e energia: conflitos no uso múltiplo das águas. Estudos Avançados, v.29, n.84, p.43-68, 2015. DOI: http://dx.doi.org/10.1590/S0103$\underline{40142015000200004}$

GRABER, J. M.; MACDONALD, S. C.; KASS, D. E.; SMITH, A. E.; ANDERSON, H. A.. Carbon Monoxide: The Case for Environmental Public Health Surveillance. Public Health Reports, v.122, n.2, p.138-144, 2007. DOI: http://doi.org/10.1177/003335490712200202

GUIMARÃES, P. R. B.. Estudo sobre as relações entre as doenças respiratórias e a poluição atmosférica e variáveis climáticas, na cidade de Curitiba, Paraná, Brasil. Tese (Doutorado em Engenharia Florestal) - Universidade Federal do Paraná, Curitiba, 2011.

IBGE. Instituto Brasileiro de Geografia e Estatística. Cidades Paraíba, Campina Grande. Brasília: IBGE, 2010.

INMET. Instituto Nacional de Meteorologia. Ministério da Agricultura, Pecuária e Abastecimento. Pressão atmosférica média de $\mathbf{2 0 0 0}$ a 2010, no município de Campina Grande. Brasília: INMET, 2010.

INSTRUTEMP. Instrumentos de Medição. Detector de Gás GasAlert Extreme SO $_{2}$. São Paulo: INSTRUTEMP, 2016a.

INSTRUTEMP. Instrumentos de Medição. ITMCO -600. Medidor de $\mathrm{CO}_{2}$. São Paulo: INSTRUTEMP, 2016c.

INSTRUTEMP. Instrumentos de Medição. LOG EXPRESS. Software para configurar o registro e a transmissão de dados do Medidor Portátil Multifuncional Modelo ITMCO -600. São Paulo: INSTRUTEMP, 2016d.

INSTRUTEMP. Instrumentos de Medição. Medidor multifuncional modelo ITMP-600. São Paulo: INSTRUTEMP, 2016b.

KAMPA, M.; CASTANAS, E.. Human health effects of air pollution. Environmental Pollution, v.151, n.2, p.362-367, 2008.

LE QUÉRÉ, C.; RAUPACH, M. R.; CANADELL, J. G.; MARLANDET, G.. Trends in the sources and sinks of carbon dioxide. Natural Geoscience, v.2, n.12, p.831-836, 2009. DOI: http://doi.org/10.1038/ngeo689

LEONI, R. C.; SAMPAIO, N. A. S.; CORRÊA, S. M.. Estatística Multivariada Aplicada ao Estudo da Qualidade do Ar. Revista Brasileira de Meteorologia, v.32, n.2, p.235-241, 2017. DOI: http://dx.doi.org/10.1590/0102-77863220005

LICKS, L. A.; PIRES, M.. Metodologia para o cálculo de emissões de carbono e da eficiência na geração de energia pela combustão do carvão fóssil no Brasil. REM: R. Esc. Minas, Ouro Preto, v.63, n.2, p.331-337, 2010.

LIMA, F. J. L.; CAVALCANTI, E. P.; SOUZA, E. P.. Avaliação do potencial eólico em cinco regiões do estado da Paraíba. Revista de Geografia, v.27, n.1, 2010.

MARIANO, J. B.. Impactos ambientais do refino de petróleo. Tese (Doutorado em Engenharia) - Universidade Federal do Rio de Janeiro, Rio de Janeiro, 2001. 
MARIN, F. R.; ASSAD, E. D.; PILAU, F. G.. Clima e ambiente: introdução à climatologia para ciências ambientais. Campinas: Embrapa Informática Agropecuária, 2008.

MASSAGARDI, M.. Diesel: Oportunidades e Desafios. In: HART WORLD FUELS CONFERENCE LATIN AMERICAN \& THE CARIBBEAN. Anais. Rio de Janeiro, 2004

MCTIC. Ministério da Ciência e Tecnologia. Emissões de gases de efeito estufa nos processos industriais e por uso de solventes. (Relatório técnico). Brasília: MCTIC, 2006.

METZ, B.; DAVIDSON, O. R.; BOSCH, P. R.; DAVE, R.; MEYER, L. A.. Contribution of Working Group III to the Fourth Assessment Report of the Intergovernmental Panel on Climate Change. Cambridge: University Press, Cambridge, United Kingdom and New York, 2007.

NAGENDRA, S. M. S.; HARIKA, P. S.. Indoor air quality assessment in a school building in Chennai City, India. WIT Transactions on Ecology and the Environment. Air Pollution Eighteen, v.136, p.275, 2010.

NAYAK, J. K.; PRAJAPATI, J. A.. Handbook on energy conscious buildings. Indian: Pilot Edition, 2006.

PEDROSO, A. N. V.. Poluentes Atmosféricos \& Plantas Bioindicadoras. São Paulo: Instituto de Botânica, 2007.

SAVEGNAGO, R. P.; CAETANO, S. L.; RAMOS, S. B.; NASCIMENTO, G. B.; SCHMIDT, G. S.; LEDUR, M. C.; Munari, D. P.. Estimates ofgenetic parameters and cluster and principal components analysesof breeding values related to egg production traits in a White Leghorn population. Poultry Science, n.90, p.2174-2188, 2011. DOI:

https://doi.org/10.3382/ps.2011-01474

SERAFIM, D. M.. A nocividade dos gases em ocorrências de incêndio. São José: UNIVALI, 2008.

SILVA JÚNIOR, J. L. R.; PADILHA, T. F.; REZENDE, J. E.; RABELO, E. C. A.; FERREIRA, A. C. G.; RABAHI, M. F.. Efeito da sazonalidade climática na ocorrência de sintomas respiratórios em uma cidade de clima tropical. J. Bras. Pneumol., v.37, n.6, p.759-767, 2011. DOI: https://doi.org/10.1590/S1806-37132011000600009

SILVA, B. B.; ALVES, J. J. A.; CAVALCANTI, E. P.; DANTAS, R. T.. Potencial eólico na direção predominante do vento no Nordeste brasileiro. Revista Brasileira de Engenharia Agrícola e Ambiental, v.6, n.3, p.431-439, 2002. DOI: https://doi.org/10.1590/S1415-43662002000300009

SILVA, E. C.; FIGUEIREDO, V. S.. Políticas públicas, segregação sócio espacial e as áreas periurbanas: contradições e impasses em torno do bairro do Ligeiro. Queimadas- PB. In: ENCONTRO LATINO AMERICANO DE INICIAÇÃO CIENTÍFICA, 14; ENCONTRO LATINO AMERICANO DE PÓS-GRADUAÇÃO, UNIVERSIDADE DO VALE DO PARAÍBA, 10. Anais. São José São Jose dos Campos: UniVAP, 2010.

SILVA, T. D.; MENEZES, M. S.. Uma discussão ambiental: o aquecimento global e a busca pelo desenvolvimento sustentável. Geografia em Atos, Presidente Prudente, n.7, v.1, 2007. DOI: https://doi.org/10.35416/geoatos.v1i7.232

SILVA, T. E. P. CARVALHO, D. O.; SILVA, M. J. P. SANTOS, N. E. S.; COSTA, P. P. R.. Enxofre: um poluente em potencial na composição do óleo diesel brasileiro. IV Congresso Brasileiro de Gestão Ambiental Salvador/BA, 25 a 28 novembro. Anais. Salvador: IBEAS, 2013b.

SILVA, T. E.; JESUS, C. A.; LEÃO, F. M. S.; MORO, P. S.; MORATO, L.. Análise preliminar de qualidade do ar e condições microclimáticas da Lapa do Sufoco, São Desidério (BA). In: CONGRESSO BRASILEIRO DE ESPELEOLOGIA, 32. Anais. Barreiras: Sociedade Brasileira de Espeleologia, 2013a. p.11-14.

SINGH, A.; AGRAWAL, M.. Acid rain and its ecological consequences. Journal of Environmental Biology, v.29, n.1, p.15-24, 2008.

SOUSA JÚNIOR, I. F.. A influência da urbanização no clima da cidade de Campina Grande-PB. Dissertação (Mestrado em Meteorologia) - Universidade Federal de Campina Grande, Campina Grande, 2006.

SOUSA, F. A. S.; MORAIS, H. F.; SILVA, V. P. R.. Influência da Urbanização no Clima da Cidade de Campina Grande-PB Revista Brasileira de Geografia Física, n.1, p.134-145, 2011. DOI: https://doi.org/10.26848/rbgf.v4.1.p134-145

SOUSA, J. B.. Estimativas de emissões e modelagem matemática da dispersão de material particulado $\left(\mathrm{MP}_{10}\right)$ oriundo das atividades da indústria cerâmica. Dissertação (Mestrado em Tecnologia) - Universidade Estadual de Campinas, Limeira, 2016.

SOUZA, V. P.; TOLEDO, R.; HOLANDA, J. N. F.; VARGAS, H.; FARIA JUNIOR, R. T.. Análise dos gases poluentes liberados durante a queima de cerâmica vermelha incorporada com lodo de estação de tratamento de água. Cerâmica, n.54, p.351-355, 2008. DOI: https://doi.org/10.1590/S0366$\underline{69132008000300013}$

VAISALA. Como medir o dióxido de carbono. São Paulo: Vaisala, 2012.

VICINI, L.. Análise multivariada da teoria à prática. Santa Maria: UFSM, 2005

A CBPC - Companhia Brasileira de Produção Científica (CNPJ: 11.221.422/0001-03) detém os direitos materiais desta publicação. Os direitos referem-se à publicação do trabalho em qualquer parte do mundo, incluindo os direitos às renovações, expansões e disseminações da contribuição, bem como outros direitos subsidiários. Todos os trabalhos publicados eletronicamente poderão posteriormente ser publicados em coletâneas impressas sob coordenação da Sustenere Publishing, da Companhia Brasileira de Produção Científica e seus parceiros autorizados. Os (as) autores (as) preservam os direitos autorais, mas não têm permissão para a publicação da contribuição em outro meio, impresso ou digital, em português ou em tradução. 